التعلم النشط وعلاقته بالفهم القرائي لاى التلاميذ ذوي صعوبات التعلم

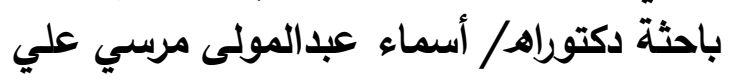

مستخلص البحث :

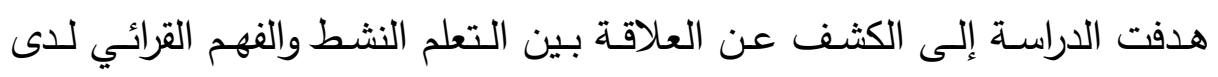

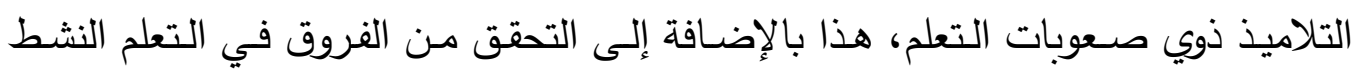
والفهم القرائي تبعا لمتغير النوع (ذكور - إناث). وبلغ عدد المشاركين في الدراسة ( . . ( )

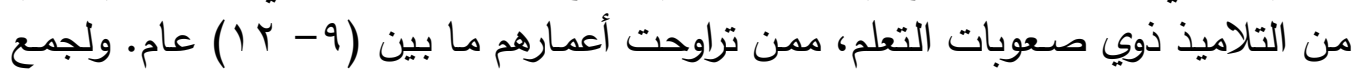

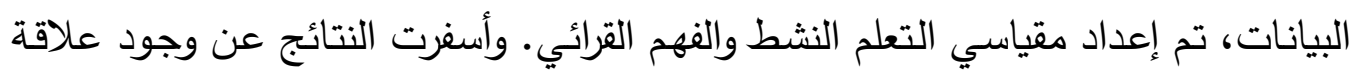

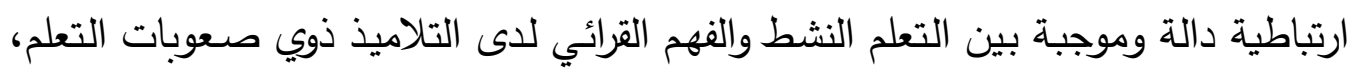

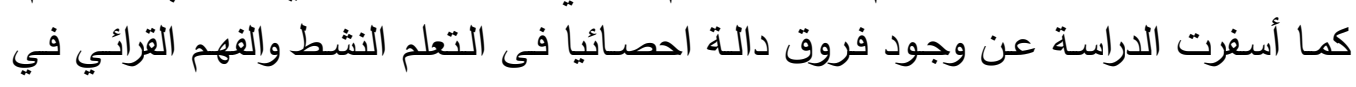
ضوء متغير النوع لصالح عينة الإناث. الكلمات المفتاحية: التعلم النشط - الفهم القرائي - صعوبات الأنات التعلم. 


$$
\begin{aligned}
& \text { عدد يناير } \\
& \text { الجزء الثانى } 9 \text { ا } 19
\end{aligned}
$$

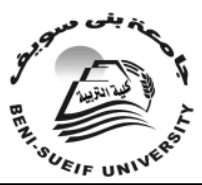

$$
\text { مجلة كلية التربية سويف }
$$

Active learning and its relationship to reading comprehension among students with learning disabilities

Asma Abdel Mawla Morsy Ali

Abstract: The study aimed to reveal the relationship between active learning and reading comprehension among students with learning disabilities, in addition to checking the differences in active learning and reading comprehension according to gender variable (males females). The number of participants in the study (100) of students with learning disabilities, who ranged in age (9-12) years. To collect data, the measures of active learning and reading comprehension were developed. The results also revealed a significant and positive correlation between active learning and reading comprehension among students with learning disabilities.

Keywords: Active Learning - Reading Comprehension - Learning Disabilities. 
تكمن الخطورة فيما يتعلق بصُعُوبات التعلم في مـا يسمى بالإعاقـة الخفية، والتي

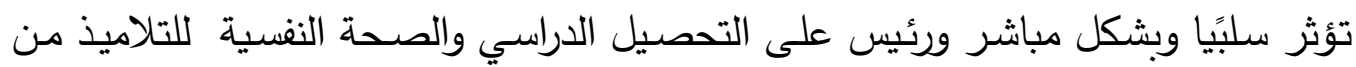

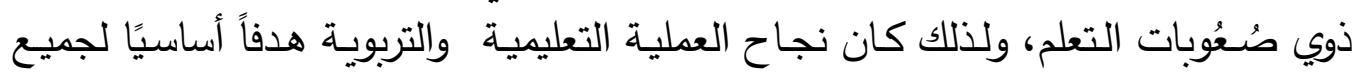

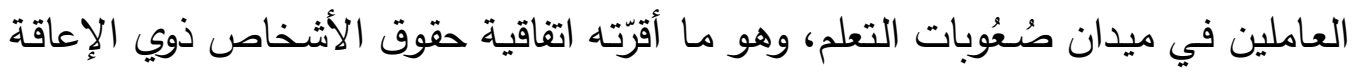

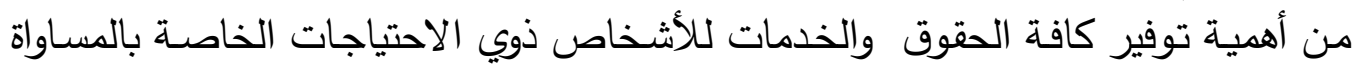

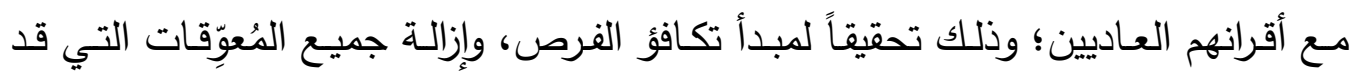

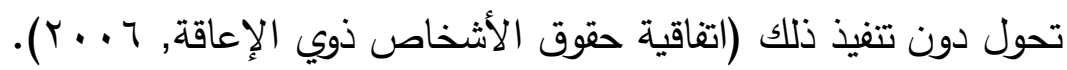

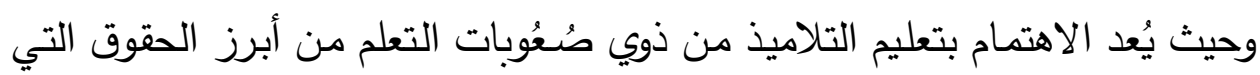

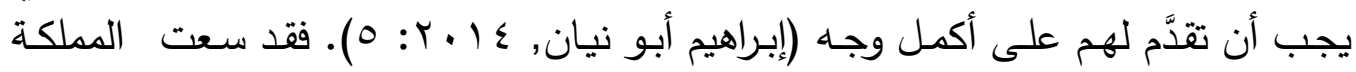

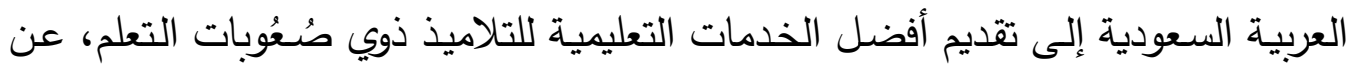

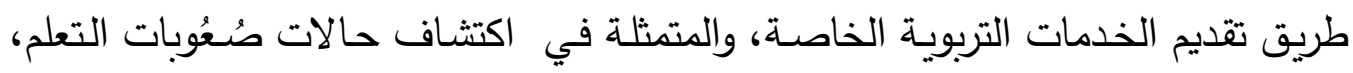

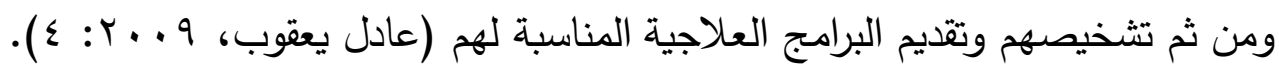

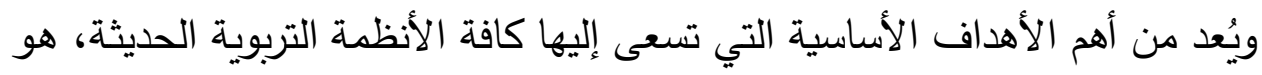

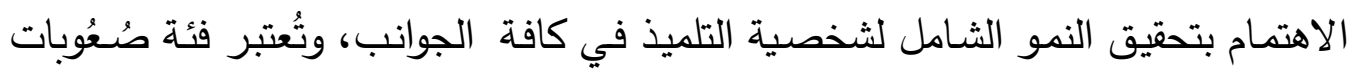

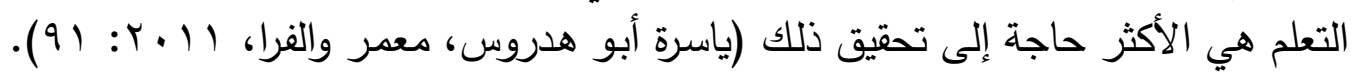

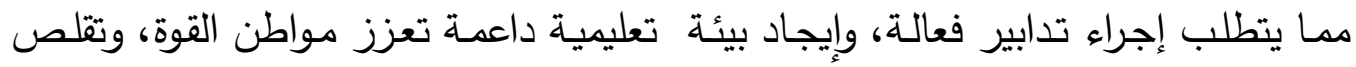

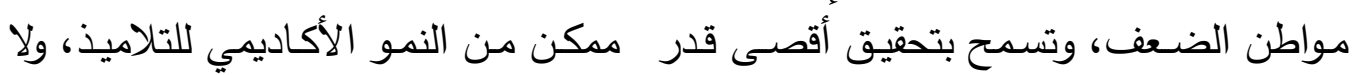

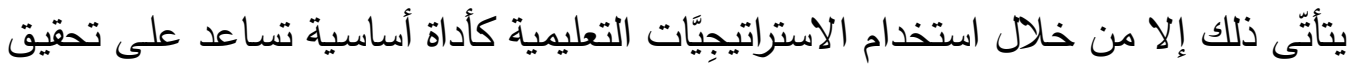
الأهداف الموضوعة، وتساهم في رفع مستوى التحصيل الدراسي، وتراعي الفروق الفردية،

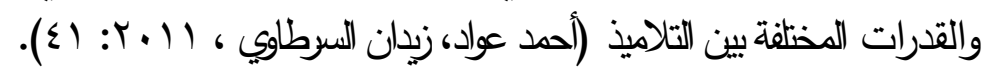

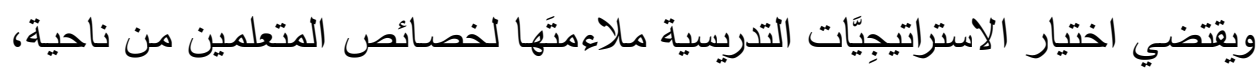

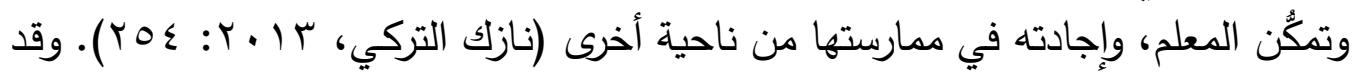

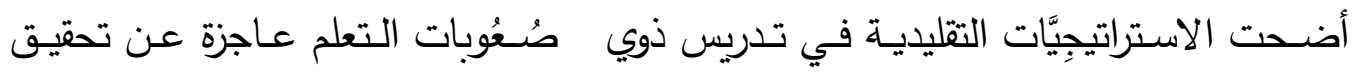

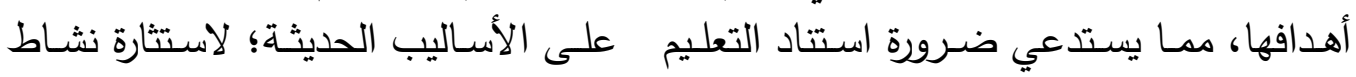

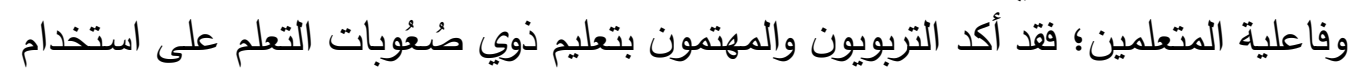

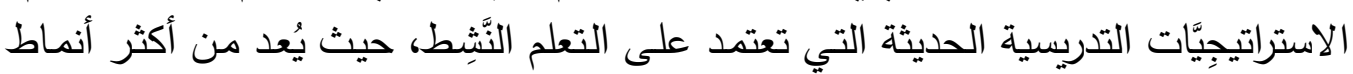

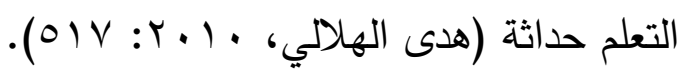




\section{عدد ينايز}

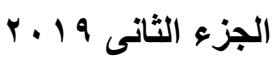

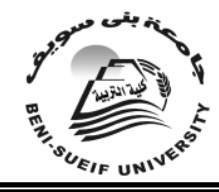

جامعة بني سويف كايفة التريفة مجلة كلية التربية

وإذ تتبثق أهمية التعلم النَّثِط من أُطُر النظريـات التربويـة الحديثة، والتطور التِتني والمعرفي، الذي تمثل في التغير الكبير لدور المعلم والمتعلم في العملية التعليمية، فلم يعُدْ

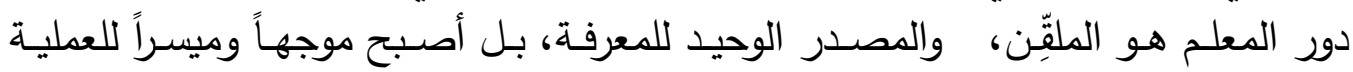

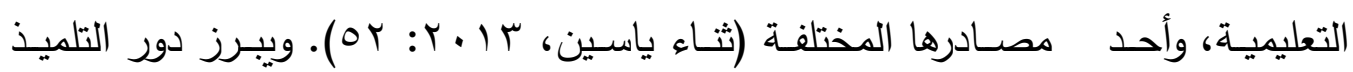
بالمشاركة الفاعلة في الأنشطة، وتطبيق ما تعلمه في الحصـة الدراسية، ويلغي الدور

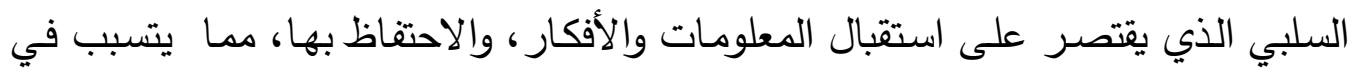
نسيانها، وعدم القدرة على تذكرها في المستقبل.

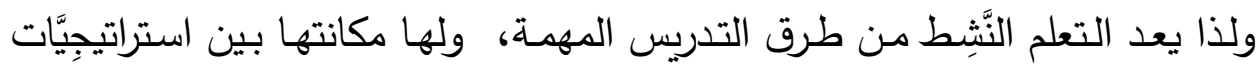

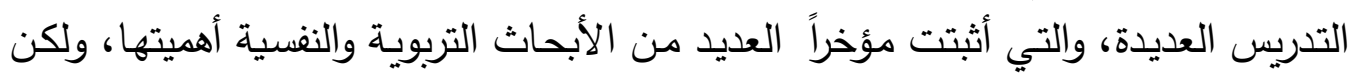

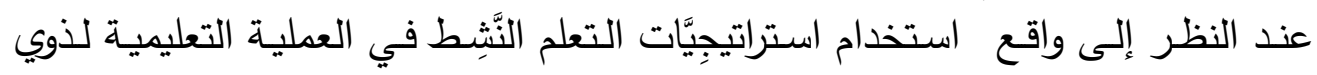

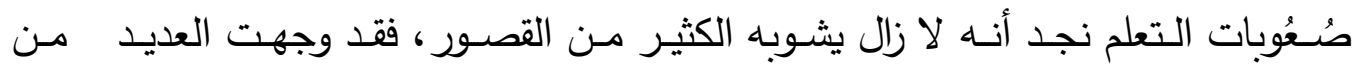

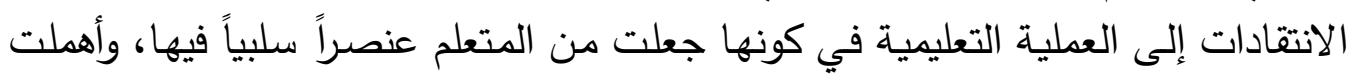

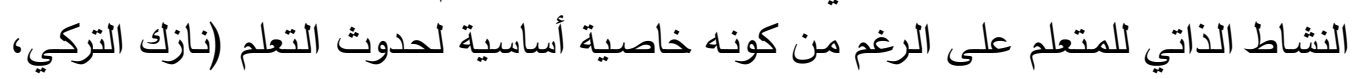

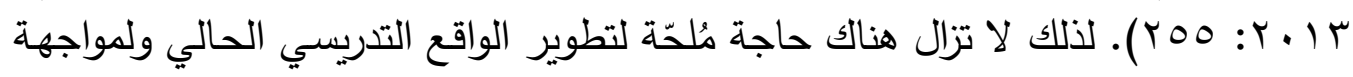

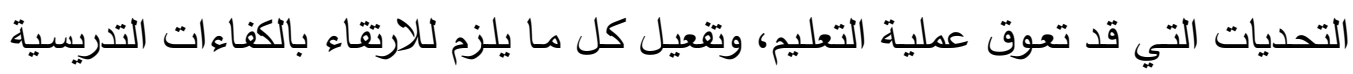
في ذلك؛ باستخدام أساليب أكثر حداثة وفاعلية من السابق.

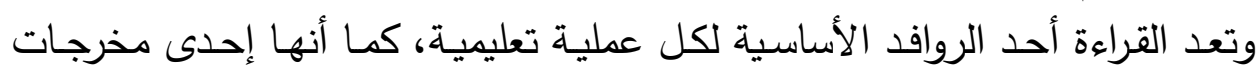

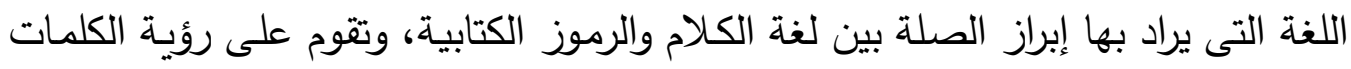
المكتوبة وإدراك معناها للوقوف على مضمونها للعمل بمقتضـاها، فهى عملية فكريـة عقلية

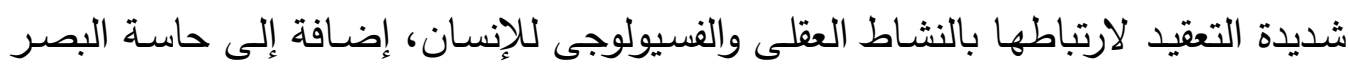

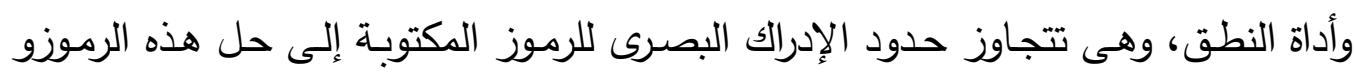

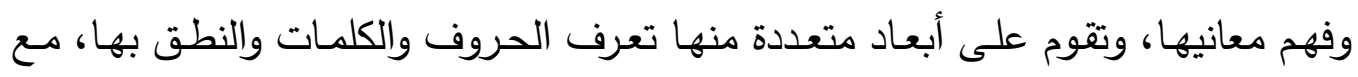

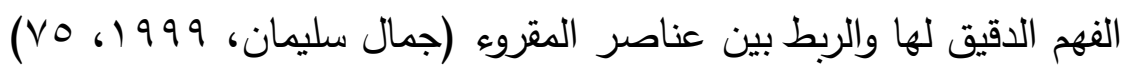

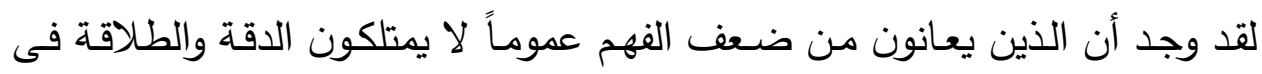

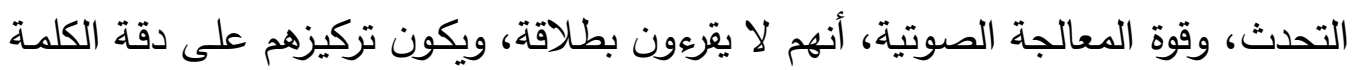

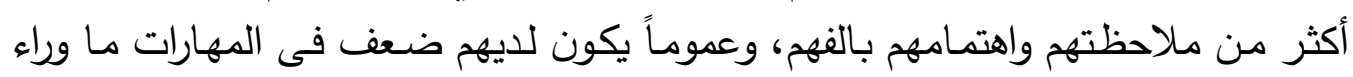

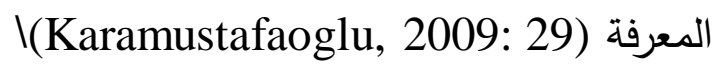
وذوى صسوبات القراءة هـ مـن يعـانون صـعوبات قرائيـة بسبب التعرض المحدود 


\section{عدد ينايز

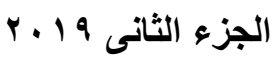

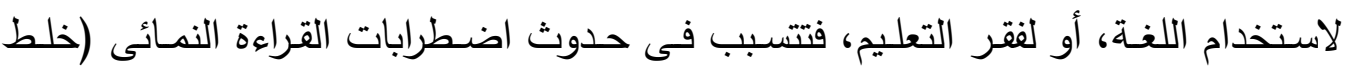

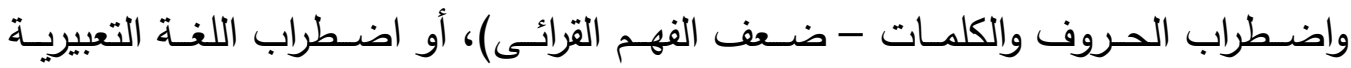
النمائى (حالات الضعف النحوى، ضعف المفردات، وتركيب الجمل الناقصة).

مثكلة الاراسـه (الآس

تتمثل مشكلة الدراسه فى وجود قصور فى التعلم النشط والفهم القرائي لدى التلاميذ

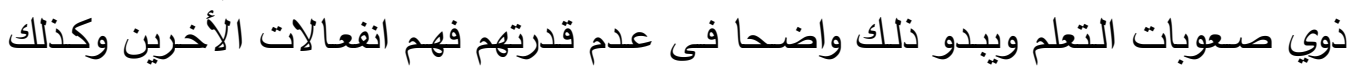

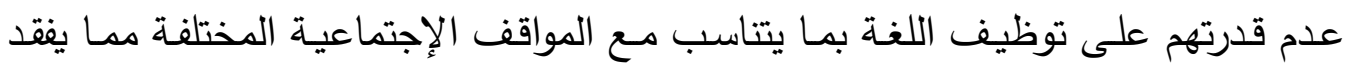
التلميذ كثيرا من قدرته على التعلم النشط والفهم القرائي الجيد مع الأخرين حيث الأبـ أن قدرته

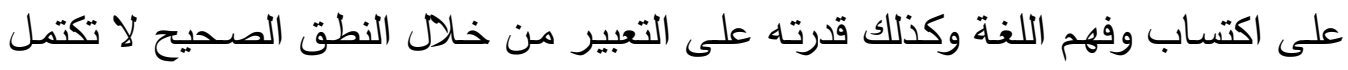

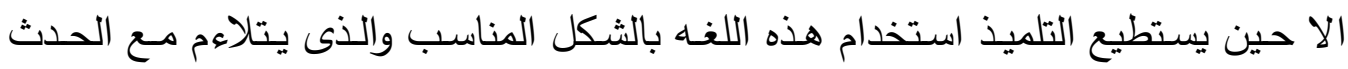

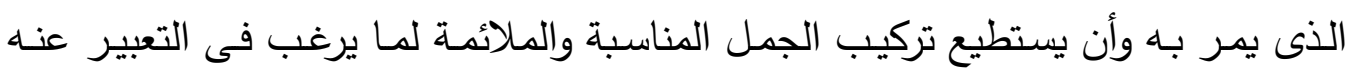
وكذلك اختيار الوقت والمكان المناسب لتوظيف الكلمات بما يفى بالغرض من بن استخدام اللغة، وتتضح مشكلة الدراسة فى القصور الواضتح لدى التلاميذ ذوي صعوبات التعلم في فئسي التعلم النشط والفهم القرائي مما قد يتسبب فى عدم قدرتهم على التقاعل مع الأخرين سواء

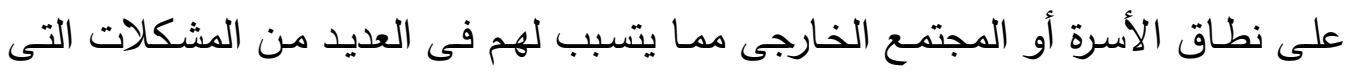

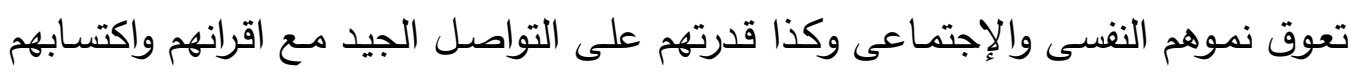
الثقة بالنفس وبناء علاقات طيبة مع الأخرين. وفى ضوء ما سبق يمكن تحديد مشكلة الدراسة فى التساؤلات الآتية:

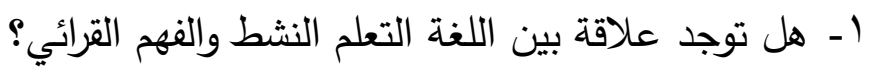

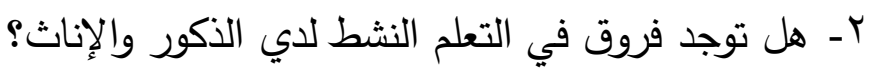

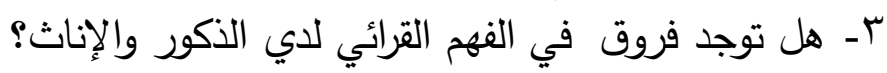

أهداف الدراسه

$$
\text { تهدف الدراسة الى التعرف على: }
$$

( ) العلاقة بين التعلم النشط والفهم القرائي. r r الفروق في التعلم النشط لدي الذكور والإناث. r) الفروق في الفهم القرائي لدي الذكور والإناث. 
ا - تتجلى أهمية الدراسة فى كونها تتصدي لفئة التلاميذ ذوي صعوبات التعلم، والتعلم

$$
\text { النشط والفهم القرائي. }
$$

r- ندرة الدراسـات العربية في هذا المجال (التعلم النشط والفهم القرائي لدى التلاديذ

$$
\text { ذوي صعوبات التعلم) وذلك فى حدود إطلاع الباحثة. }
$$

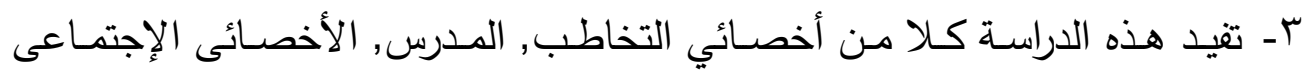

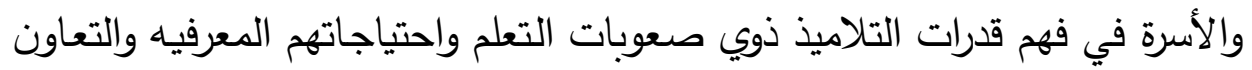
كفريق تدريبى للحد من قصور التعلم النشطوما لذلك من أكبر الأثر في تتميـة مهارات الفهم القرائي لدياه.

مصطلحات الدراسه موارت

التلاميذ ذوي صعوبات التعلم:

هـم الـذين يبـدون اضـطراباً فـى واحـدة أو أكثر مـن العمليـات النفسـية الأساسـية

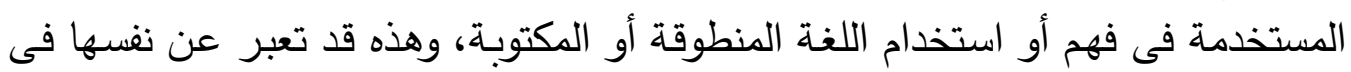

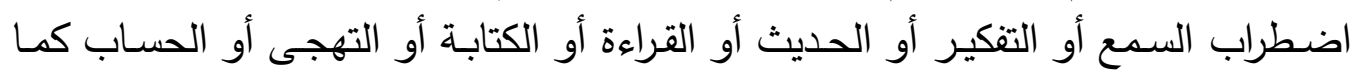

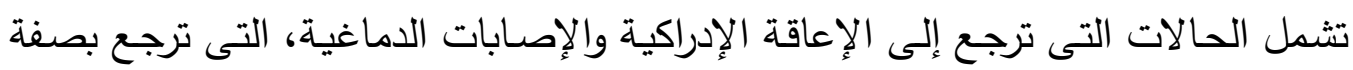

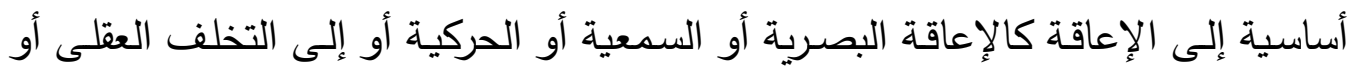
الاضطراب الانفعالى أو الحرمان البيئى .(Karamustafaoglu, 2009: 30).

التعلم النشط:

لأساليب والإجراءات التي تقوم على التفاعل المشترك بين المعلم والتلاميذ من ذوي

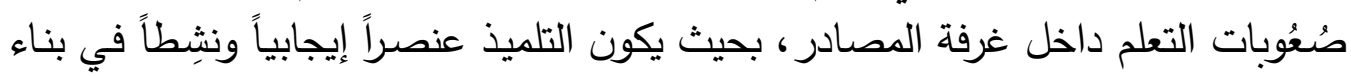

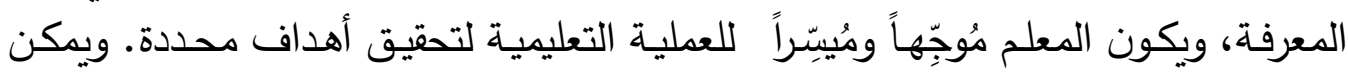
قياسه من خلال (اللرجة الكلية لمجموع استجابات التلميذ نى صعوبات التعلم على مقياس التعلم النشط). الفهم القرائي:

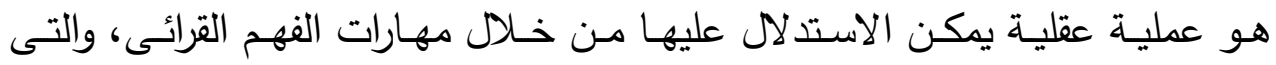

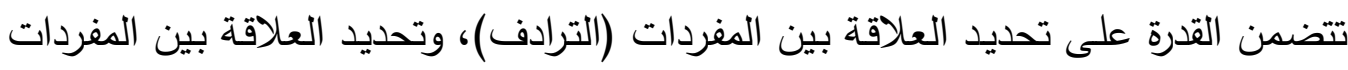

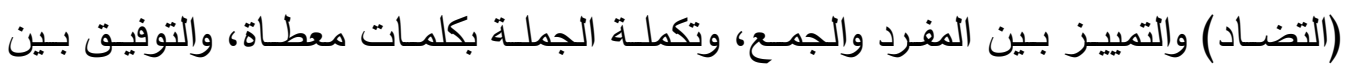

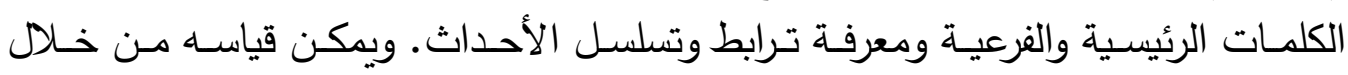
(الدرجة الكلية لمجموع استجابات التلميذ ذى صعوبات التعلم على اختبار الفهم القرائى). 
تم تطبيق الأدوات في أحد المدارس الابتدائية بمدينة مغاغة بمحافظة المنيا.

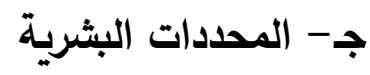
تكونت عينة الدراسة من · الم من التلاميذ ذوي صعوبات التعلم، وتراوحت أعمار

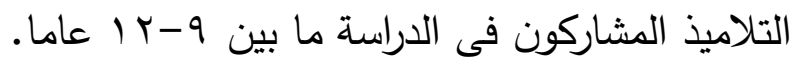

ع - المحددات المنهجية

تم استخدام المنهج الوصفي المقارن.

دراسات سابقه

أولا: دراسات تناولت التعلم النشط لاتى التلاميذ ذوي صعوبات التعلم: تتاولت دراسة (Filippatou \& Kaldi, 2010) مدى فعالية التعليم القائم على دولى دان المشاريع وهو من استراتيجِيَّات التعلم النَّتِط في رفع مستوى التحصيل الدراسي، وزيـادة

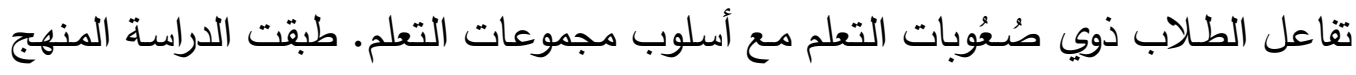

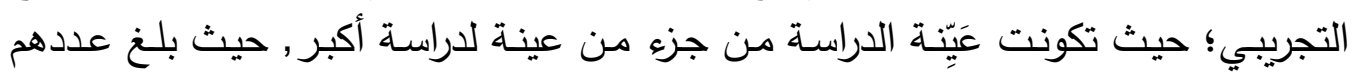

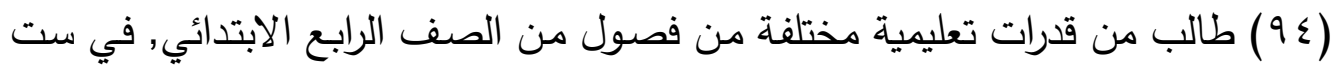

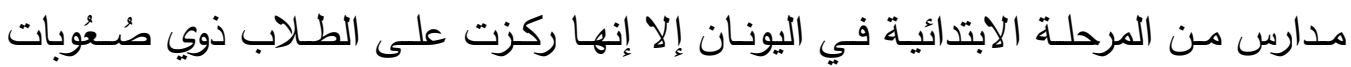

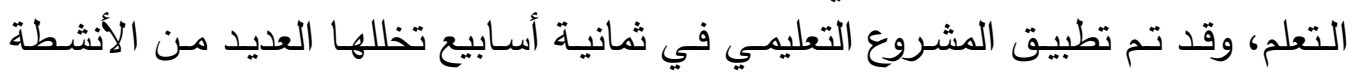

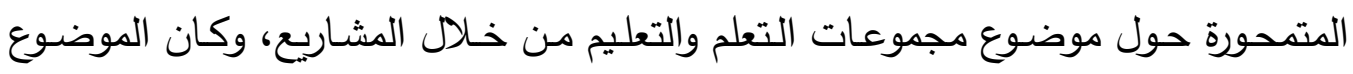

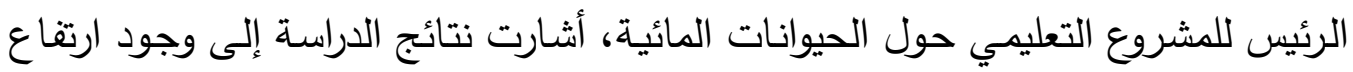

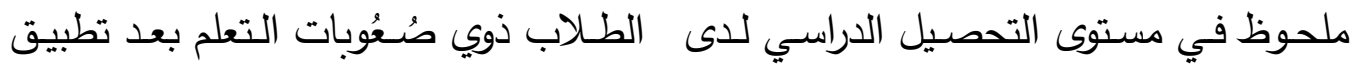

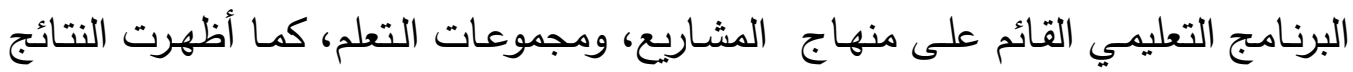
تفضيل الطلاب لأسلوب التعليم التجريبي عن التعليم التقليدي؛ وذلك لأنَّهَ يؤدي إلى زيادئ

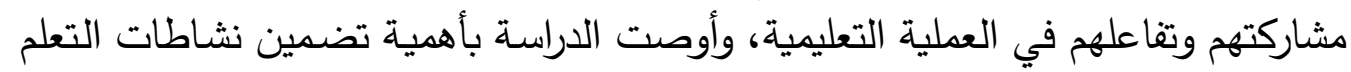
القائم على المشاريع ومجموعات التعلم في المنهاج الدراسي، وذلك لفاعليته في تفعيل دور الطالب في العملية التعليمية. 


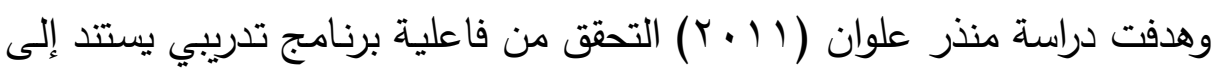

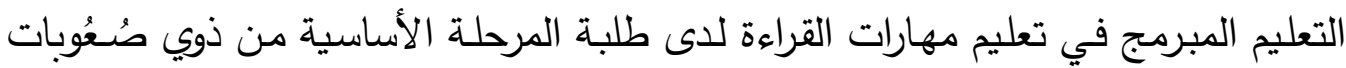

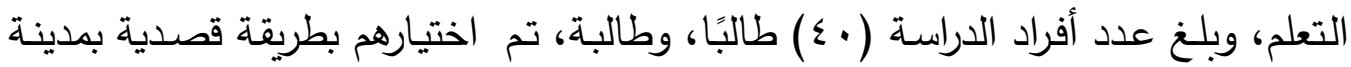
عمان، وتم توزيعهم إلى مجموعتين: ضابطة، وتجريبية، وقد أعد الباحث مقياسًا لاختبار

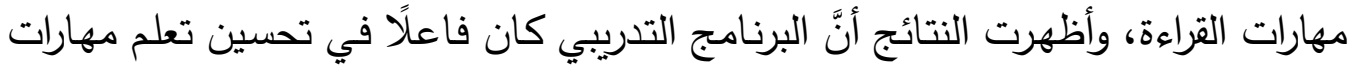
القراءة لدى التلاميذ ذوي صُعُوبات التعلم؛ حيث توجد فروق في مهارات القراعة لصالح المجموعة التجريبية.

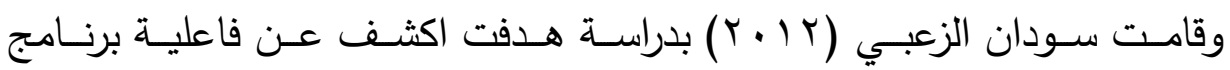

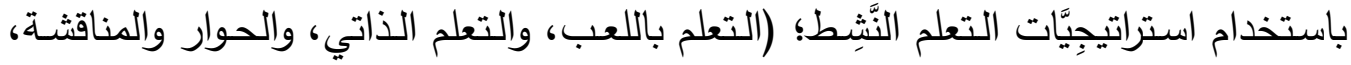

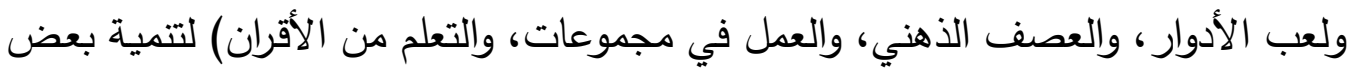

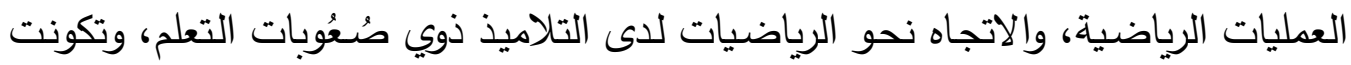

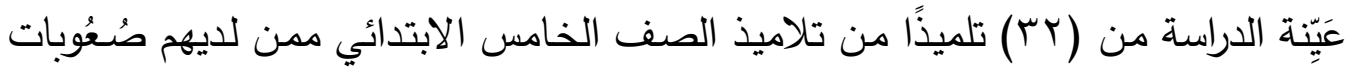

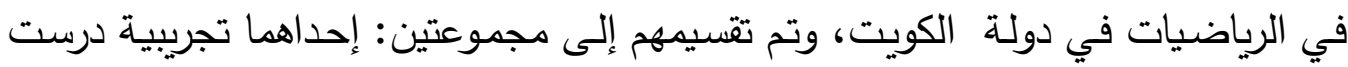

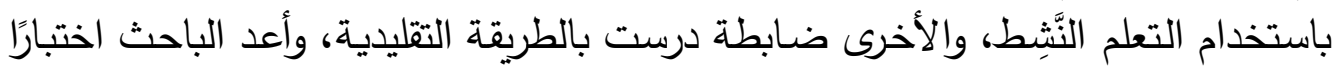

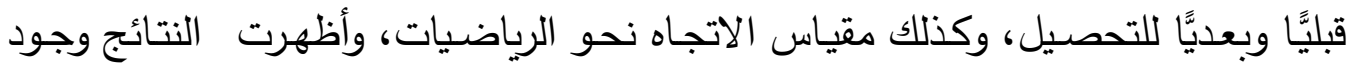
فروق ذات دلالة إحصائية لاختبار التحصيل، ومقياس الاتجاه نحو الوياضيات لصالح المجموعة التجريبية.

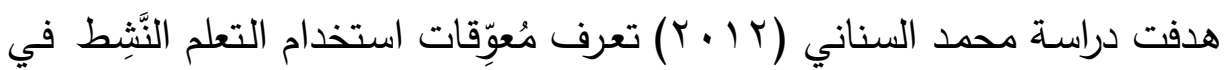

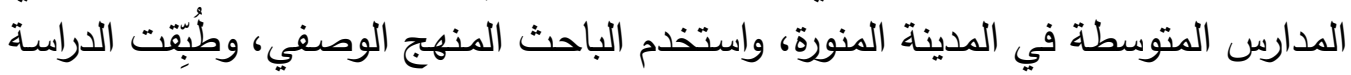

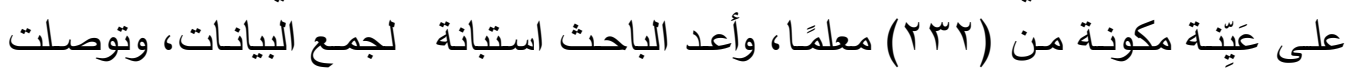

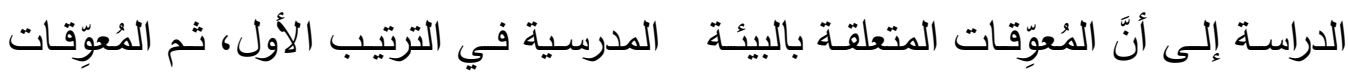

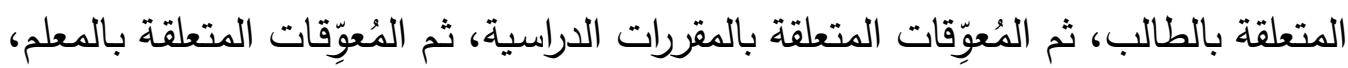

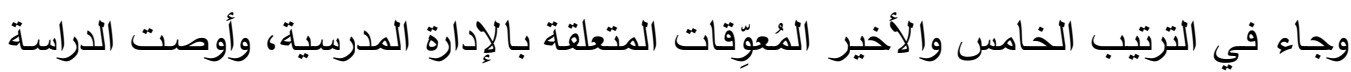

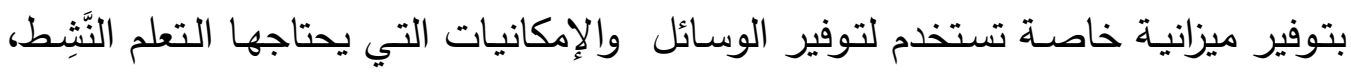

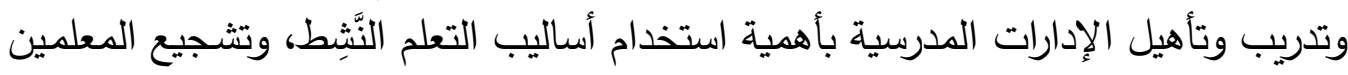

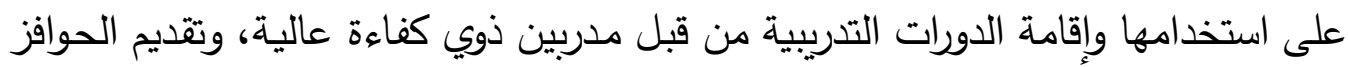
المعنوية والمادية للمعلمين الذين يستخدمون التعلم النَّشِط.

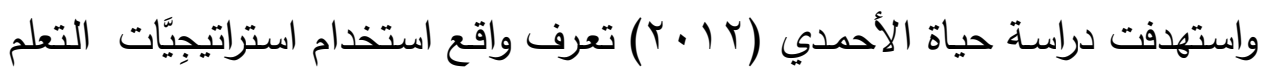

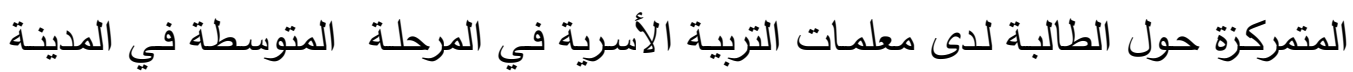

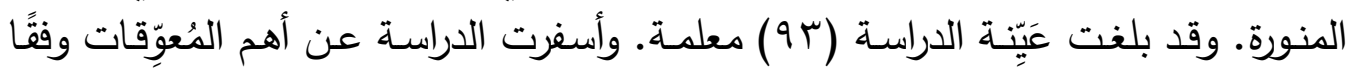


للترتيب الآتي: كثرة أعداد الطالبات في الفصل الدراسي، ضعف الإمكانيات المادية في

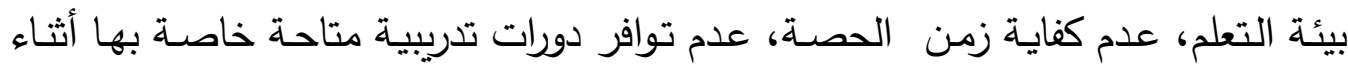

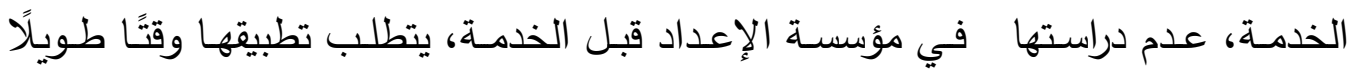

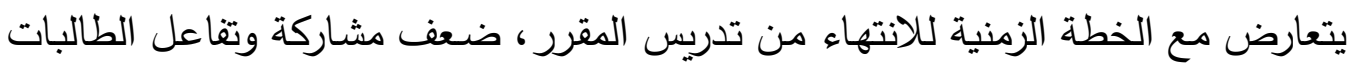
عند استخدامها، صعوبة ضبط الفصل أثناء استخدامها. وجاء ترتيب المقترحات المدكنة لرفع مستوى استخدامها تبعًا للرجة الأهمية كالآتي: التعريف بالمواقع التعليمية على شبكة التهاء

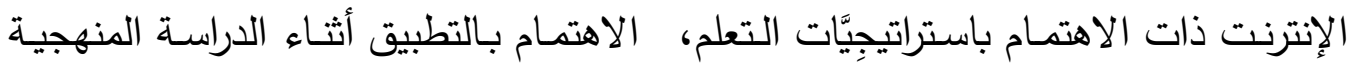

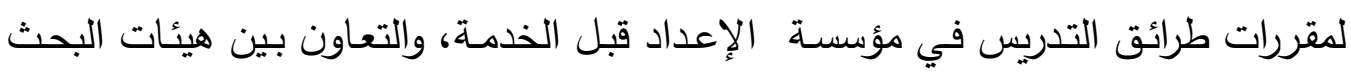

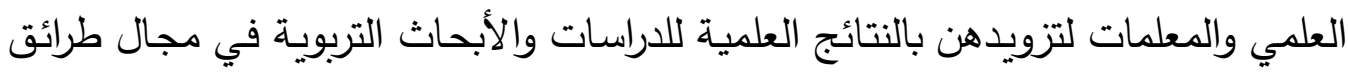

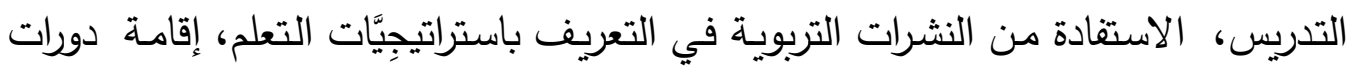

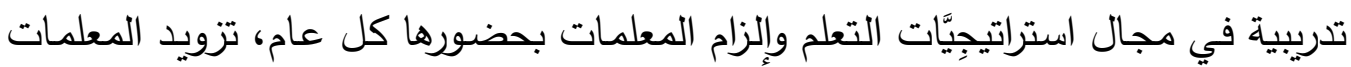

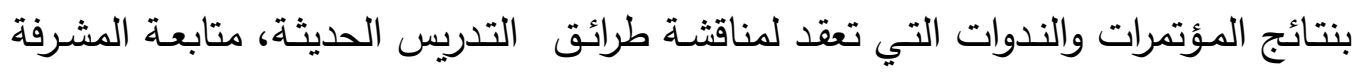
التربوية لاستخدام طرائق تدريس حديثة من قبل المعلمات.

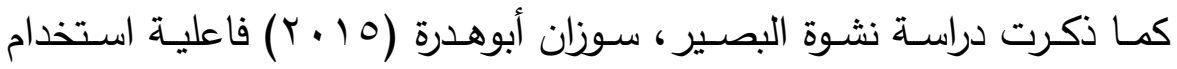

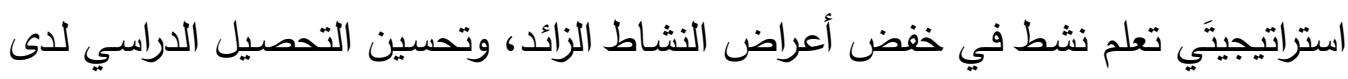

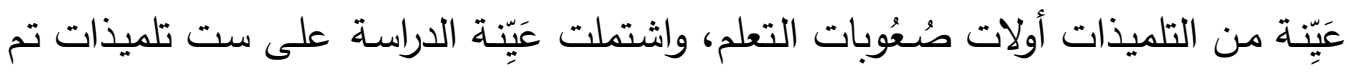

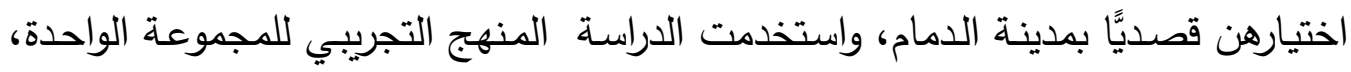

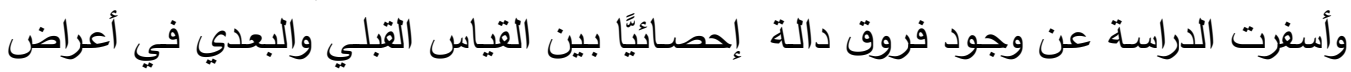

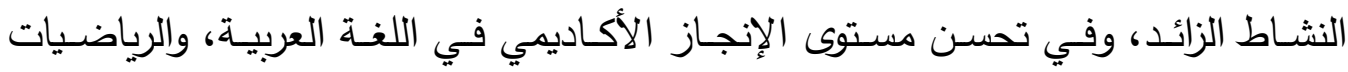

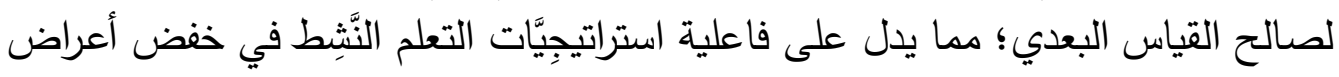

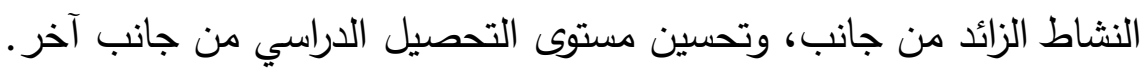

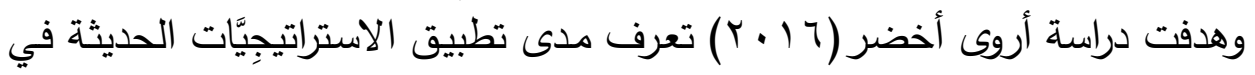

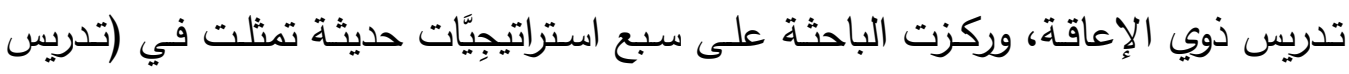

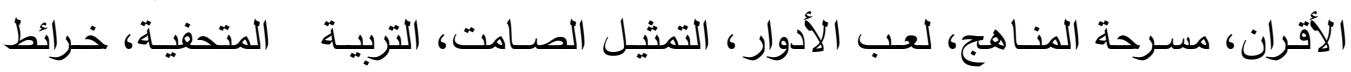

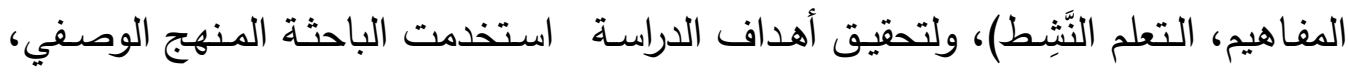

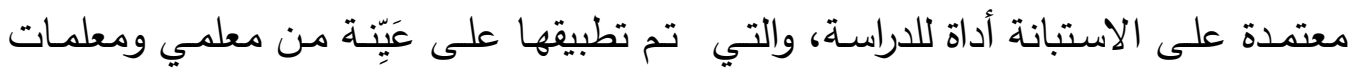

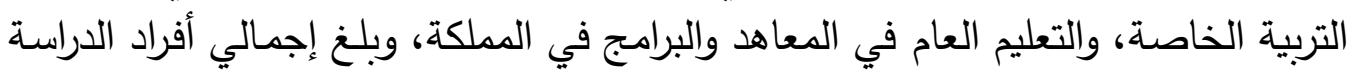
(Vo) معلمًا، ومعلمة، وتبين أنَّ من أهم مُعوّقِات تطبيق استراتيجِيَّات التدريس الحديثة: 
كثافة المحتوى الدراسي، ونقص بعض الأدوات والأجهزة في المدرسة، وقصور استخدام

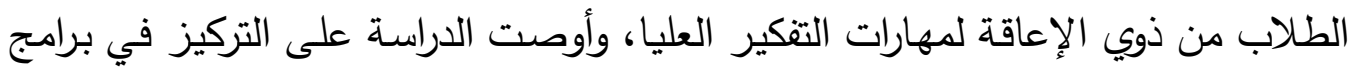

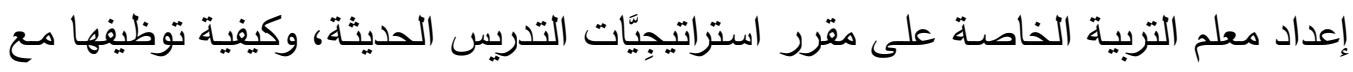
ذوي الإعاقة، وعقد دورات تدربيية للمعلمين أثناء الخدمة. وهدفت دراسة (Sencibaugh \& Sencibaugh, 2016) تعرف مدى فاعلية تطبيق استراتيِِيَّات التعلم التعاوني في رفع مستوى التحصيل الدراسي لدى الطلاب ذوي ندي

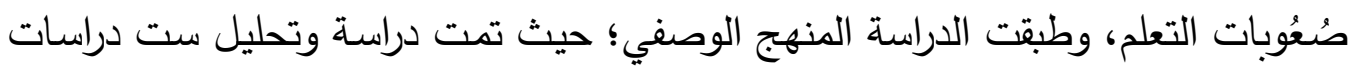

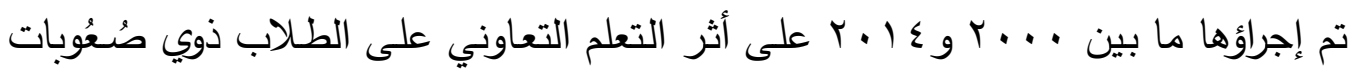

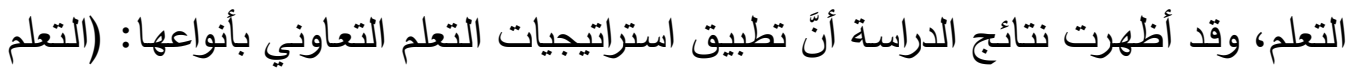

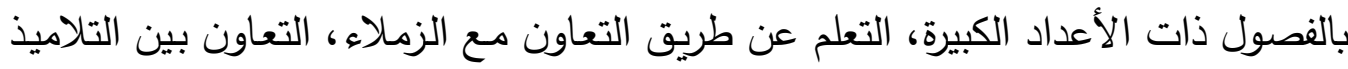

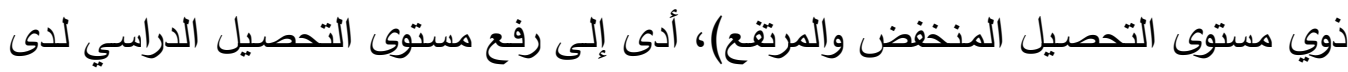

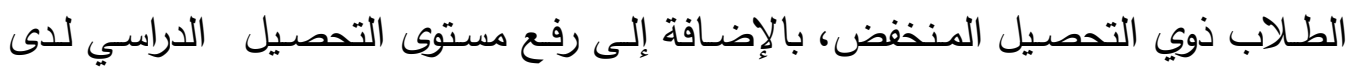

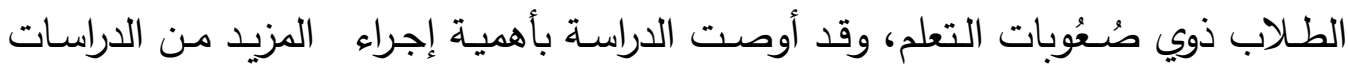

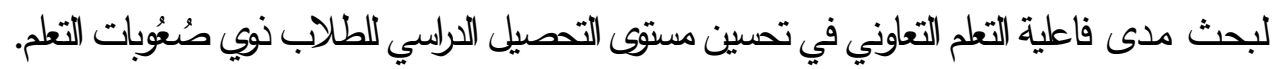

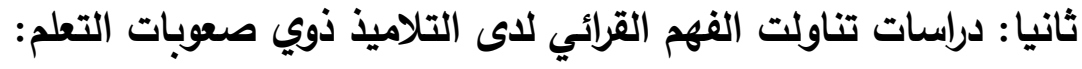
هدفت دراسة (Jacobucei et al., 2012) إلى إجراء برنامج علاجى لتحسي لتحسين الفهم

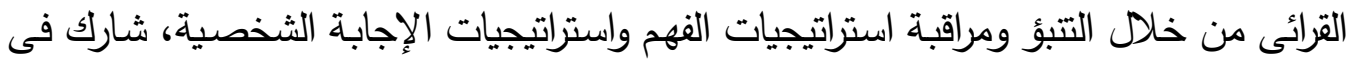

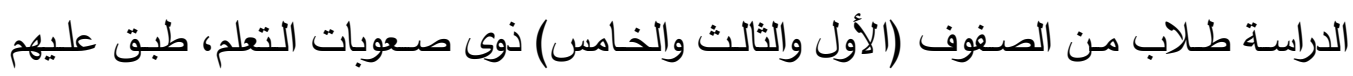
الأدوات التالية (اختبار الفهم القرائى، برنامج علاجى لتحسين الفهم القرائى إعداد الباحث) وقامت الدراسة باستعراض مشكلات انخفاض التحصيل الدراسى من خلال ملاحظات المعلمين

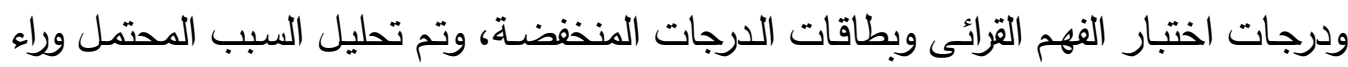

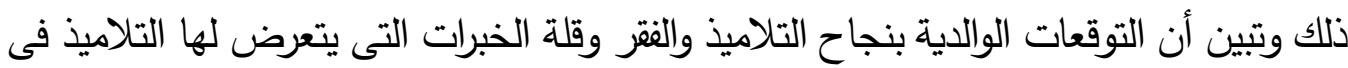

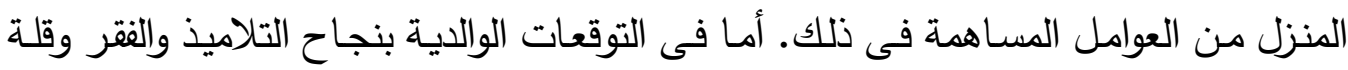

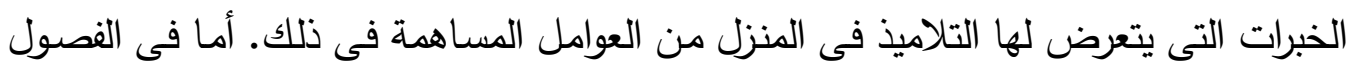

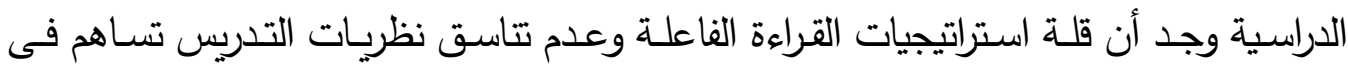

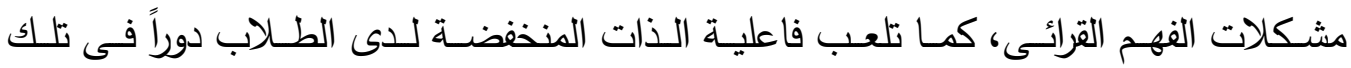

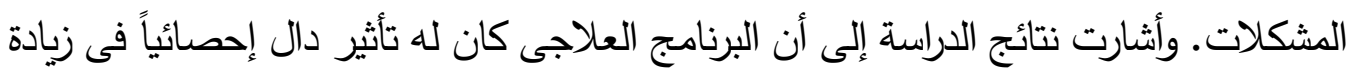




\section{عدد يناير

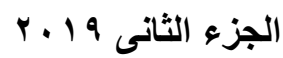

مشاركة الطلاب والاهتمام بالقراءة، وكذلك تحسن مهارات الفهم القرائى. كما ظهرت لدى عينة الدراسة زيادة فى المهارات التعليمية والمسئولية الداخلية والثخصية عن التعلم. وهدفت دراسـة (Grunke \& Sonntag, 2013) إلى معرفة أثر برنامج قائم على التعلم التصنيفى فى تتمية الفهح القرائى لدى الطلاب ذوى صسوبات التعلم، شارك فى الدراسـة

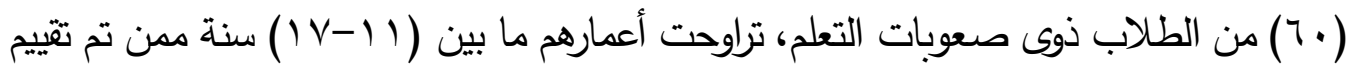
الفهم القرائى لديهم مسبقاً، تم تقسيمهم إلى مجموعتين: مجموعة تجربيية تضم ( • (ب) طالباً، مجموعة ضابطة تضم ( • ب) طالباً، طبق عليهم الأدوات التالية (اختبار الفهم القرائى - برنامج قائم على التعلم التصنيفى من إعداد الباحث) . وتم تطبيق البرنامج حيث تم تقديم قائمـة مكونـة من (Y0) كلمة مصنفة فى خمسة تصنيفات للمجموعة التجريبية، وطلب منهم تذكر هذه القائمة

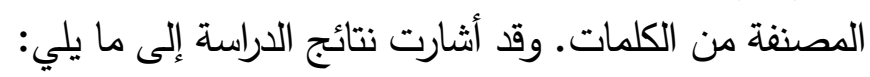
أ- وجود علاقة إيجابية بين الفهم القرائى وعدد الكلمات الصحيحة المتذكرة. ب - كما أشارت الحراسة إلى أهمية التخريب المكثف على مهارات القراءة للطلاب ذوى صعوبات التطلم. ومن تدريب المجموعة التجريبية على المراقبة الذاتيـة أثتاء (التلخيص و التوضيح و

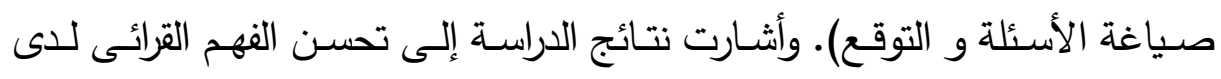
التلاميذ ذوى صعوبات التعلم بدرجة كبيرة نتيجة الدمج بين الاستراتيجيات المعرفية التى تتضمن (التلخيص و التوضيح و صياغة الأسئلة و التوقع)، واستراتيجية واحدة من استراتيجات ما وراء المعرفة وهى المراقبة الذاتية). وقد عمل Nevo \& Bar-Kochva (2015) دراسة للتعرف على العلاقة بين الذاكرة العاملة ومهارات القراءة المبكرة مثل تذكر أصـوات الكـلام على نمو مهارات القراءة المتقدمة، وقد استمرت الدراسـة من التمهيدي إلى الصف الخامس الابتدائي. وتكونت العينة

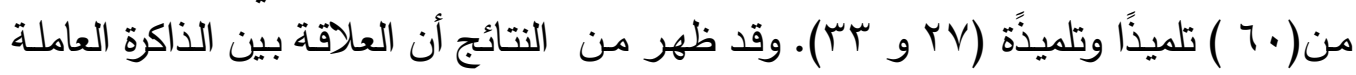
ومهارات القراءة الأساسية كانت أكثر وضوحا في الصفين الأول والثاني من المرحلة الابتدائية، مع وجود علاقة تتبؤيه بين الذاكرة العاملة وفهم المادة المقروءة في الصف الخامس الابتدائي. ويرى الباحثان أن هذه الدراسة نؤكد العلاقة بين الذاكرة العاملة والفهم القرائي على المدى الطويل . وأجرى (Georgious \& Das (2016) دراستين: الأولى على (IV^) طالبًا جامعيا، تبين من نتائجها أن التخطيط فقط هو المؤشر ذو الدلالة الإحصائية على الفهم القرائي، وأن تأثير الذاكرة العاملة لم يكن ذا دلائة إحصائية على الفهم والدراسـة الثانية على ( ب) طالباً جامعيًا، ظهر من نتائجها أن أداء الطلاب الذين لديهم ضعف في مهارات الفهم كان أداؤهم أقل 


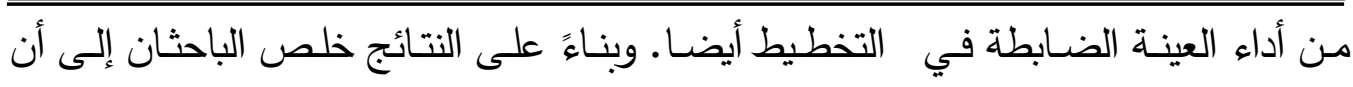
التخطيط هو أحد مكونات الوظائف التتفيذية هو الذي يلعب دورًا ذا دلالة في علاقته بالفهر. تعقيب على الاراسات السابقة:

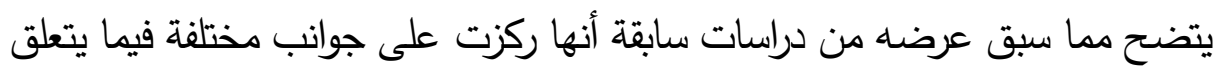
بكل متغير من متغيرات الدراسة، وأهملت جوانب أخري هامة، وما الدراسة الحالية إلا محاولة

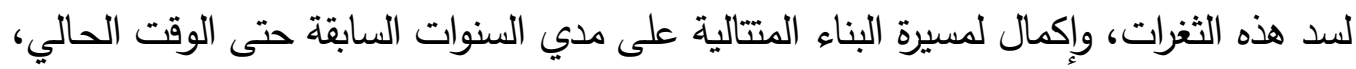

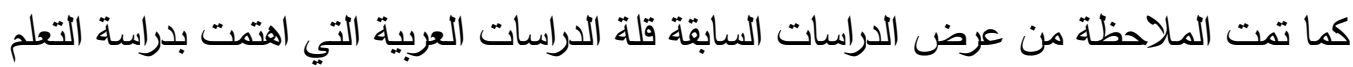

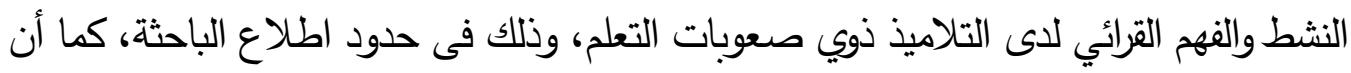
كل الدراسات التي اهتمت بدراسة التعلم النشط والفهم القرائي لدى التلاميذ ذوي صعتئ صعوبات التعلم دراسات أجنبية، وذلك فى حدود اطلاع الباحثة.

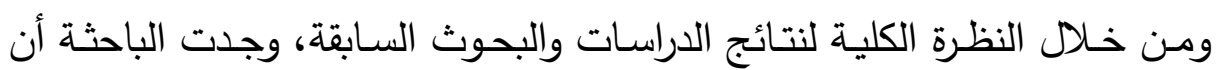
التلاميذ ذوي صعوبات التعلم يعانون من قصور واضح فى التعلم النشط والفهم القرائي. أوجه الاستفادة من الاراسات السابقة:

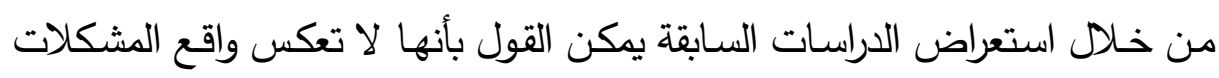

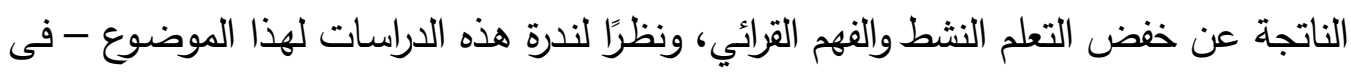

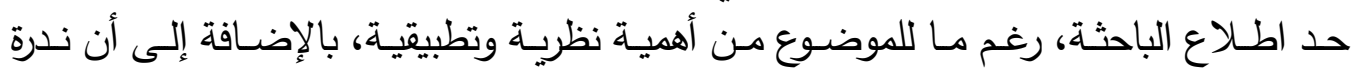

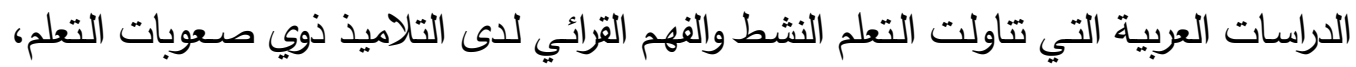

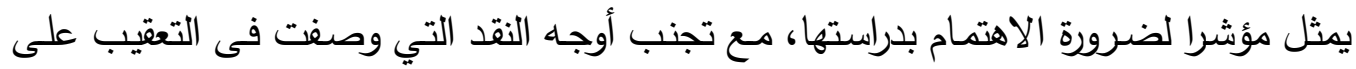
الدراسات بهدف الوصول إلى نتائج أكثر قابلية للتعميم، بالإضـافة إلى التى اختلاف التهاف الدراسة الحالية

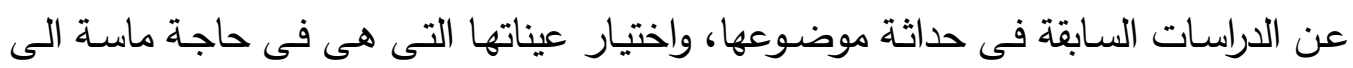
المساندة من قبل الآخرين، وقد استفادت الباحثة من البحوث والدراسات السابقة وما توصلت وإتئي إليه

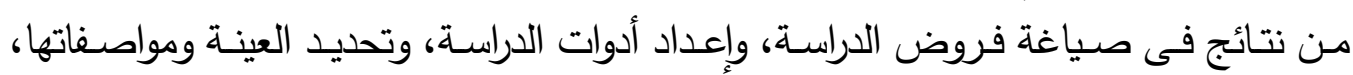

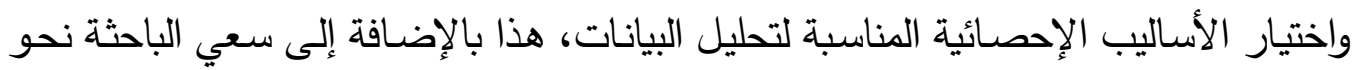

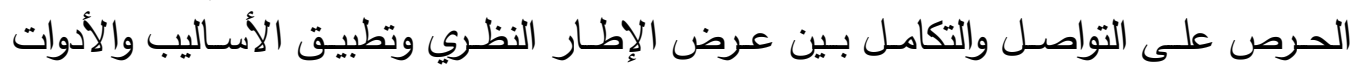

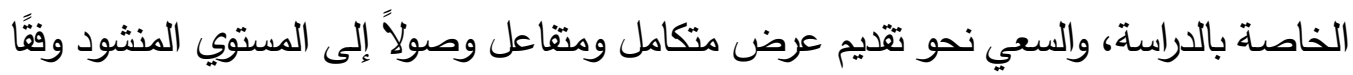

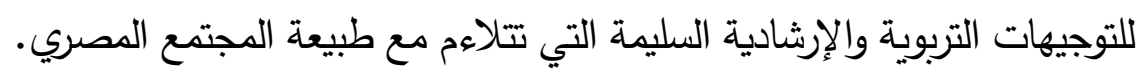


فروض الاراسة

ا ـ توجد علاقة ذات دلالة احصائية بين التعلم النشط والفهم القرائي لدى التلاميذ

$$
\text { ذوي صعوبات التعلم. }
$$

Y. توجد فروق ذات دلالة احصائية بين متوسطي درجات التعلم النشطلى النكور والإثاث. باء توجد فروق ذات دلالة احصائية بين متوسطي درجات الفهم القرائي للى النكور والإثاث.

إجراءات الدراسة:

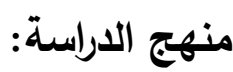

اعتمدت الدراسة الحالية على المنهج الوصفي المقارن.

عينة الاراسة:

أُجريت الدراسة على عينة من التلاميذ نوي صعوبات التعلم، وق تم تقييمه إلى مجموعتين:

1 - عينة التحقق من الخصائص السيكومترية:

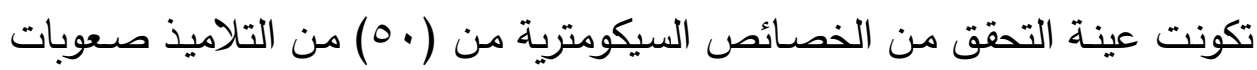

التعلم، تراوحت أعمارهم ما بين (9 - r T I ) عاما.

r - ب العينة الأسناسية:

تكونت العينة الأساسية من ( . . ( ) من التلاميذ ذوي صسعوبات التعلم منهم ( •. )

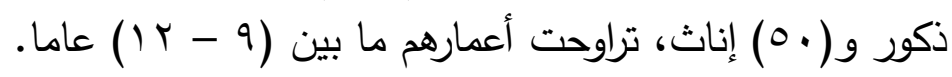
أدوات الدراسة:

استخدمت الباحثة فى دراستها الأدوات التالية:

1- مقياس التعلم النشط (إعداد: الباحثة). مبررات إعداد المقياس:

( ) معظم الأدوات المستخدمة فـى الدراسـات السـابقة غيـر ملائمسة مـن حيث الصياغة اللفظية، وقد تصلح لأعمار تختلف عن أعمار عينة الدراسة.

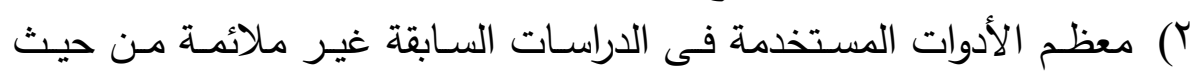
طول العبارة نفسها، والتعامل مع عبارات طويلة جدًا يؤدى إلى ملل وتعب هؤلاء الأقراد. ץ) معظم المفردات والأبعاد فى المقاييس المابقة غير مناسبة لطبيعة عينة الدراسة. ع) يتاول البحث الحالى مرطة عمرية لم تتوفر لها مقاييس ملأمة لقياس التعلم النثط.

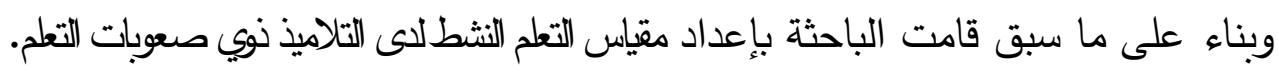

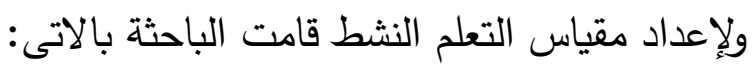


أ- الإطلاع على الأُطر النظرية والكثير من الدراسات السابقة التى تتاولت التعلم النشط. ب- تم الإطلاع على عدد من المقاييس التى استُخدِمت لقياس التعلم النشط. ج · فى ضوء ذلك قامت الباحثة بإعداد مقياس التعلم النشط، مكونًا من (7 ( ) مفردة.

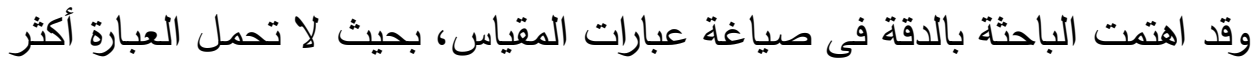

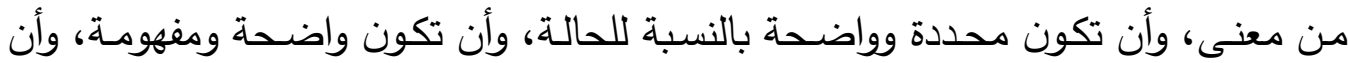

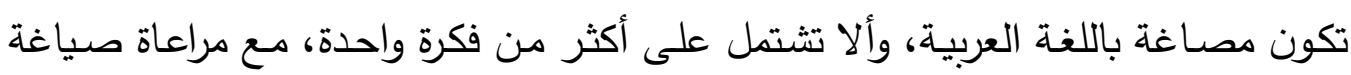
العبارات فى الاتجاه الموجب.

الخصائص السيكومترية لمقياس التعلم النشطاه أولاًَ- حساب صدق المقياس:

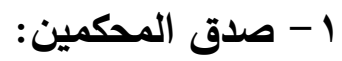

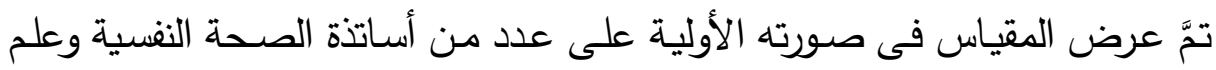

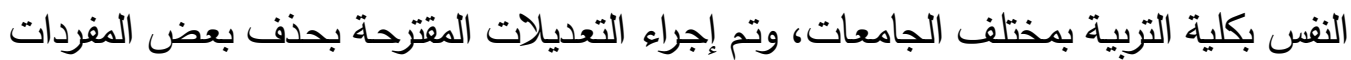

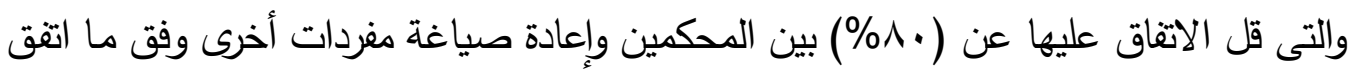

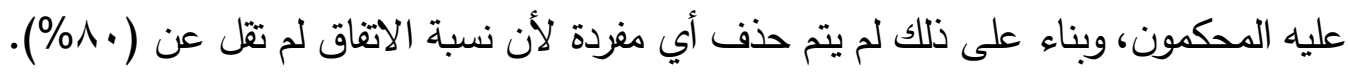
r - الصدق التمييزى (المقارنة الطرفية): تم حساب صدق المقياس عن طريق المقارنة الطرفية (صدق التمايز)، وذلك بترتيب التهابـ

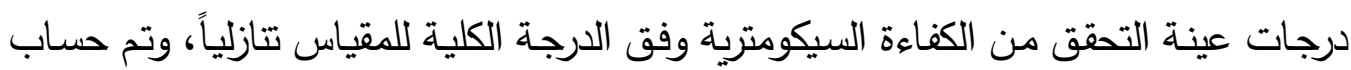
دلالة الفروق بين متوسطى درجات الإرباعى الأعلى والإبراعى الأننى، والجلول ( () يوضح تلاك.

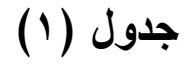

صدق المقارنة الطرفية لمقياس التعلم النشط

\begin{tabular}{|c|c|c|c|c|c|}
\hline \multirow{2}{*}{ مستوى الدلالة } & \multirow[b]{2}{*}{ قيمة ت } & \multicolumn{2}{|c|}{ الإرباعى الأدنى ن= Ir } & \multicolumn{2}{|c|}{ الإرباعى الأعلى ن=س 1} \\
\hline & & الانحراف المعياري & الحسابي & الانحراف المعياري & الحسابي \\
\hline$\cdot, ., 1$ & $|r, r \wedge|$ & 1,01 & $1 \wedge, 0$. & $r, Y Y$ & $\leq \curlyvee, \wedge \vee$ \\
\hline
\end{tabular}

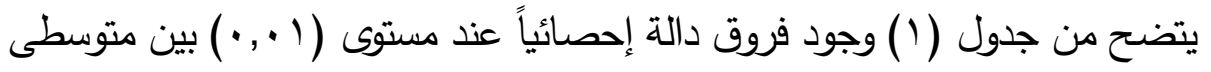
درجات التلاميذ ذوى المستوى المرتفع وذوى المستوى المنخفض، وفى اتجاه المستوى المرتفع، مما يعنى تمتع المقياس بصدق تمييزى قوى. 
تمَّ ذلك بحساب ثبات مقياس التعلم النشط لدى التلاميذ ذوي صعوبات التعلم للتلاميذ

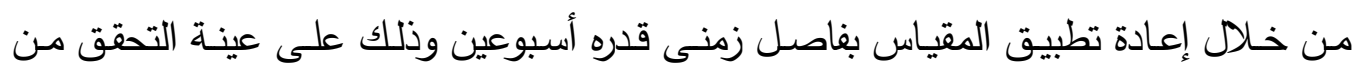
الكفاءة السيكومترية، وتم استخراج معاملات الارتباط بين درجات تلاميذ العينة باستخدام معامل فلئل

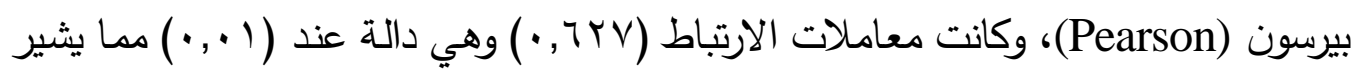

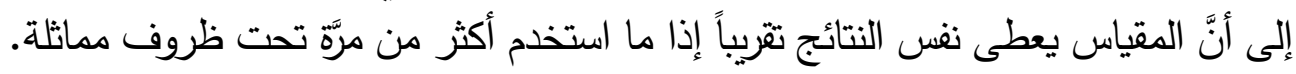

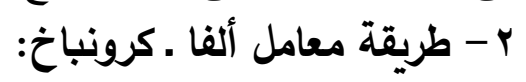

تمَّ حساب معامل الثبات لمقياس التعلم النشط لدى التلاميذ ذوي صعاموبات التعلم

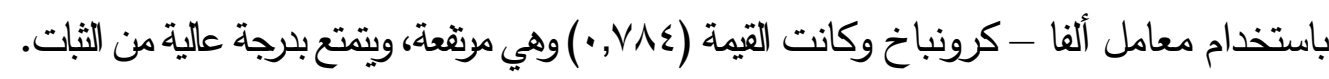
r- بريقة التجزئة النصفية: قامت الباحثة بتطبيق مقياس التعلم النشط لدى التلاميذ ذوي صعوبات التعلم على التى

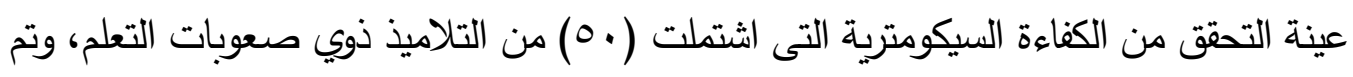

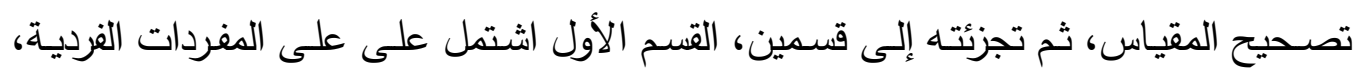

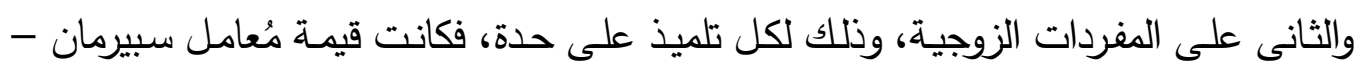

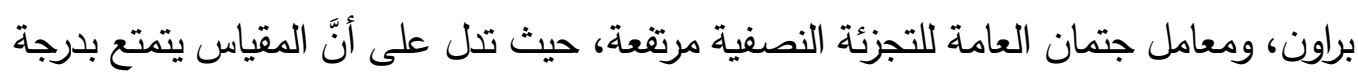

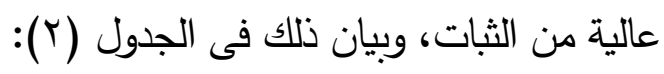

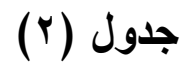

مُعاملات ثبات مقياس التعلم النشط بطربقة التجزئة النصفية

\begin{tabular}{|c|c|}
\hline جتمان & سبيرمان ـ براون \\
\hline$\cdot, \vee>9$ & $\cdot, \wedge \cdot \wedge$ \\
\hline
\end{tabular}

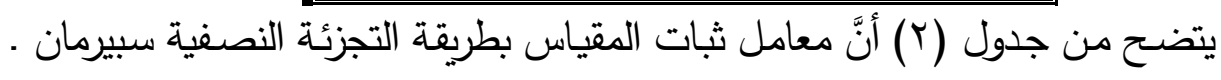

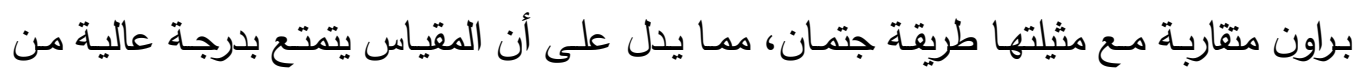
الثبات فى قياسه للتعلم النشط. ثالثا - الاتساق الداخلي: تئل

وذلك من خلال درجات عينـة التحقق من الكفاءة السيكومترية بإيجاد معامل ارتباط

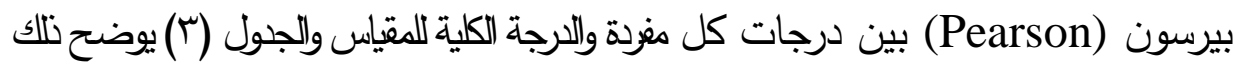


قامت الباحثة بإعداد اختبار للفهم القرائى وفقاً للخطوات التالية:

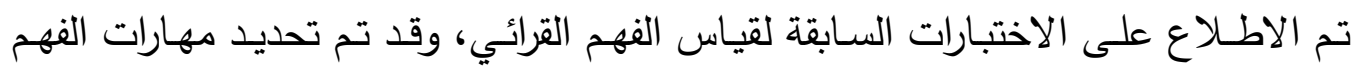
القرائى المراد قياسـها وتتميتها وهـى ( التعرف على معـان المفردات الجديدة بـالنص التمييز بين الجمع والمفرد - التعرف على التضاد المفردات- تكملة الجملة بكلمات معطاةترتيب الكلمات لتكوين جملة مغيدة- معرفة تزلط الأحداث فى القصة- فهم علاقات السبب بالنتيجة). أولا - صدق الاختبار : ترتب

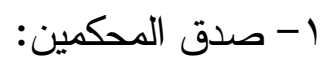

قد تم عرض الصورة الأولية للاختبار على المحكمين بلغت (• (1) عشرة محكمين

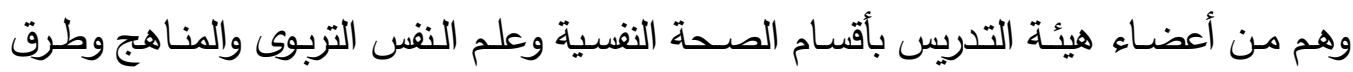

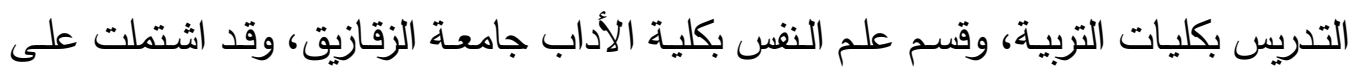
التعريف الإجرائى لمهارات الفهم القرائى بالإضـافة إلى نموذج التحكيم تضمن المهارات المراد

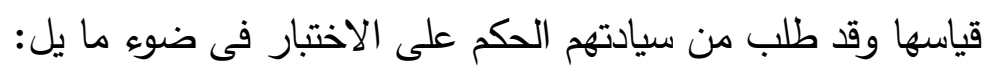

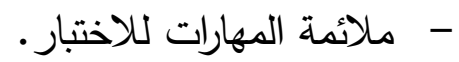

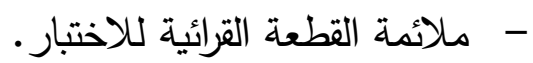

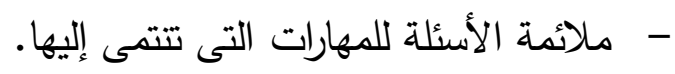
- - إضافة أي مقترحات أو ملاحظات. قام الباحث بإعداد الصـورة المعدلـة مـن الاختبار بعد إجراء التعديلات والمقترحات الصادرة من السادة المحكمين ومن هذه المقترحات:

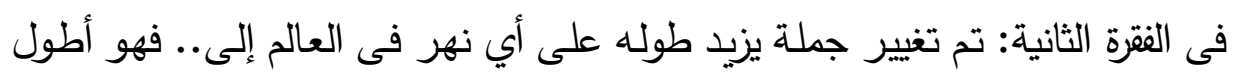

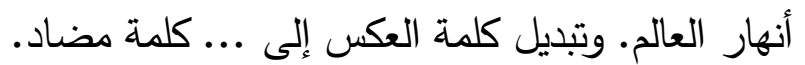
فى الفقرة الرابعـة: تم تبديل بعض العـادات النافعـة من (حب القبل القراءة، احترام الكبير والعطف على الصغير إلى ... علم القاء القمامة فى الثارع وغسل الين قبل التبل الأكل وبعده).

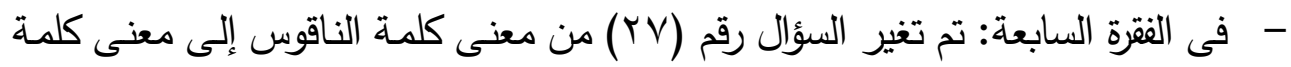

$$
\text { يستيظظ (يصحو - ينام - يمشى). }
$$


الخصائص السيكومترية لاختبار الفهم القرائى

ا - الصدق التمييزى (المقارنة الطرفية):

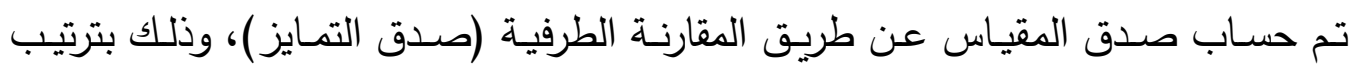

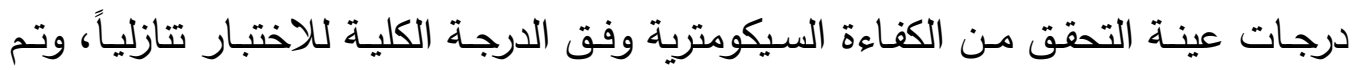

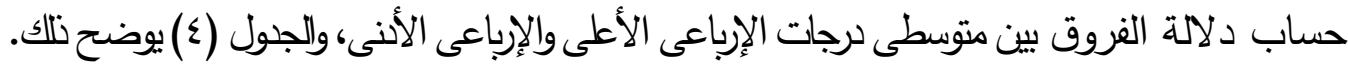

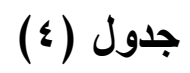

صدق المقارنة الطرفية لاختبار الفهم القرائى (أع

\begin{tabular}{|c|c|c|c|c|c|c|}
\hline \multirow{2}{*}{ مستوى } & \multirow[b]{2}{*}{ ق ق قيمة ت } & \multicolumn{2}{|c|}{ الإرباعى الأدنى= $1 \mathrm{H}$} & \multicolumn{2}{|c|}{ الإرباعى الأعلى= 1 IT } & \multirow{2}{*}{ لارباعى الأعلى } \\
\hline & & المعيارى & المتوسط & المعيارى & المتوسط & \\
\hline.,. .1 & $I \varepsilon, \Delta Y$ & $r, 0$. & $\triangle \wedge, \wedge \varepsilon$ & $1, r$. & $V \varepsilon, Y T$ & الدرجة الكلية \\
\hline
\end{tabular}

يتضـح مـن جدول (ع) وجـود فـروق دالـة إحصـائياً عند مسـتوى (1 (., •) بـين

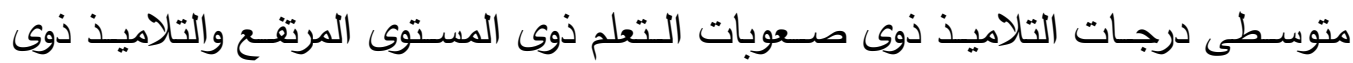

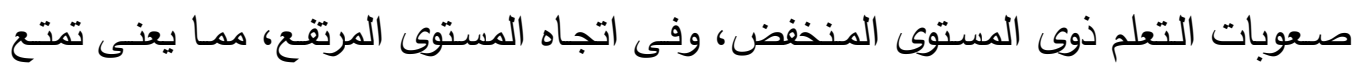
الاختبار وأبعاده بصدق تمييزى قوى. ثانياً: ثبات الاختبار : الاخداده 1 - طريقة إعادة تطبيق الاختبار:

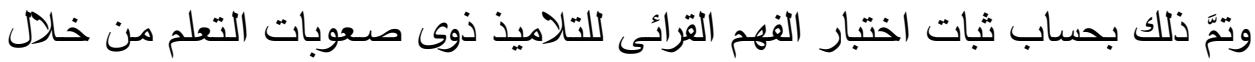

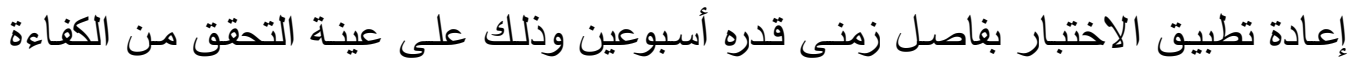

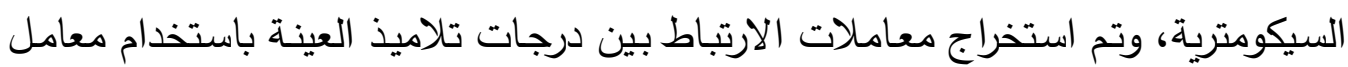

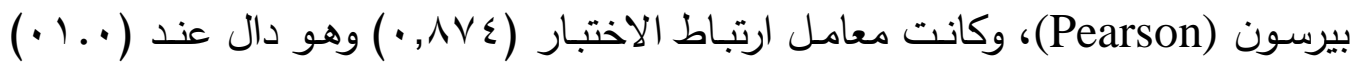

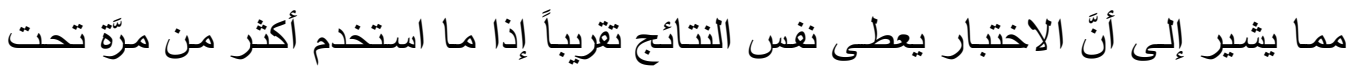
ظروف مماثلة. r - بريقة معامل ألفا ـ كرونباخ:

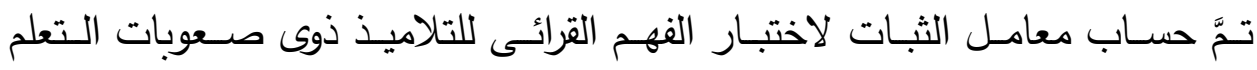

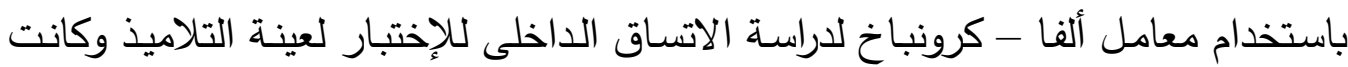

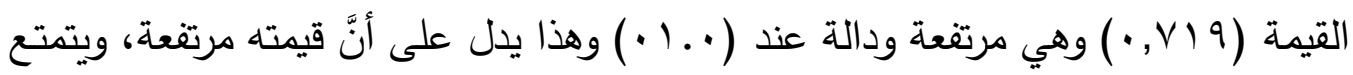
بدرجة عالية من الثبات. 
قامت الباحثة بتطبيق اختبار الفهم القرائى للتلاميذ ذوى صسعبات التعلم على عينة

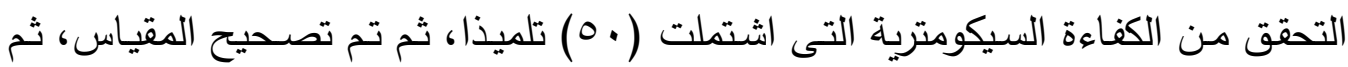

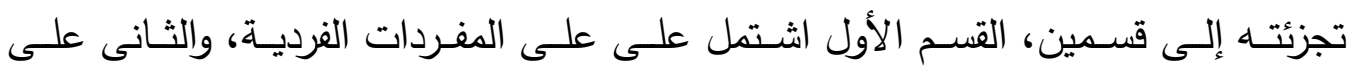

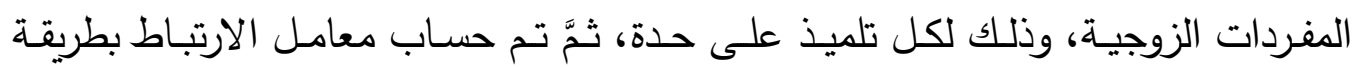
بيرسون (Pearson) بين درجات المفحوصين فى المفردات الفردية، والمفردات الزوجية، ودئ

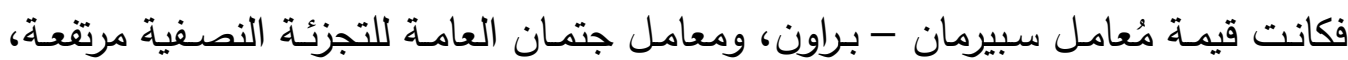
حيث تدل على أنَّ الاختبار يتمتع بدرجة عالية من الثبات، وبيان ذلك فى الجدول (0): جدول (0)

مُعاملات ثبات اختبار الفهم القرائى للتلاميذ نوى صعوبات التعم بطريقة التجزئة النصفية

\begin{tabular}{|c|c|c|}
\hline مستوى الدلالة & جتمان & سبيرمان ـ براون \\
\hline $.1 .$. & vri.. & $900 .$. \\
\hline
\end{tabular}

يتضـح مـن جـدول (0) أنَّ معـاملات ثبـات الاختبـار بطريقـة التجزئسـة النصـفية

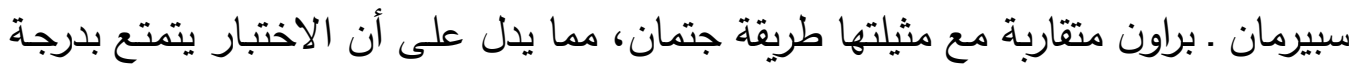
عالية دن الثبات فى قياسه للفهم القرائى.

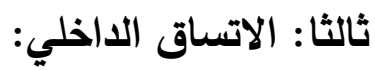
وذلك من خلال درجات عينة التحقق من الكفاءة السيكومترية بإيجاد معامل ارتباط

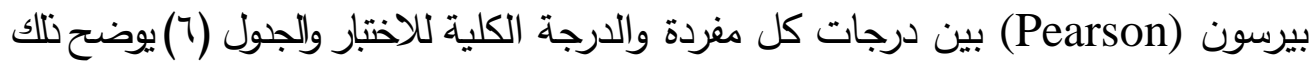
جدول (7)

معاملات الارتباط بين درجات كل مفردة والدرجة الكلية لاختبار الفهم القرائى

\begin{tabular}{|c|c|c|c|c|c|c|c|}
\hline معامل الارتباط & م & معامل الارتباط & م & معامل الارتباط & م & معامل الارتباط & م \\
\hline ***ฯฯ... & $\varepsilon r$ & $* * \vee 0$. & rq & *\%०... & 10 & *ז.. & 1 \\
\hline *\%ו.. & $\varepsilon \varepsilon$ & *\%ץ.. & r. & $* *,\{01$ & 17 & * * & r \\
\hline$* *, \leqslant \Gamma q$ & $\leqslant 0$ & $* * \diamond \wedge .$. & M & 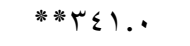 & iv & $* * \varepsilon \cdot V$. & $r$ \\
\hline$* 01 \mathrm{~V}$. & $\varepsilon 7$ & $* * \varepsilon \varepsilon \varepsilon \ldots$ & rr & *ศน & 11 & $* * 0 \wedge 9$. & $\varepsilon$ \\
\hline$* * \eta \cdot r$. & $\Sigma V$ & **ڤ1.. & rr & *\%ץr.. & 19 & 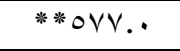 & 0 \\
\hline *\%ץ.. & $\sum \Lambda$ & $* \%$ oV. & $r \leq$ & *rצ.. & $r$. & **ศๆ. & 7 \\
\hline **\% $*$... & $\varepsilon q$ & $* 991 .$. & ro & **\%ฯ & YI & *rov.. & V \\
\hline$* * \leqslant \neg .$. & 0. & $* * \Sigma Y$. & T & 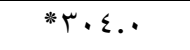 & rr & **orา. & $\wedge$ \\
\hline$* * \varepsilon \cdot r .$. & 01 & $* *, 0 \wedge 1$ & rv & **\%ฯ & rr & *\%०ᄉ. & 9 \\
\hline
\end{tabular}




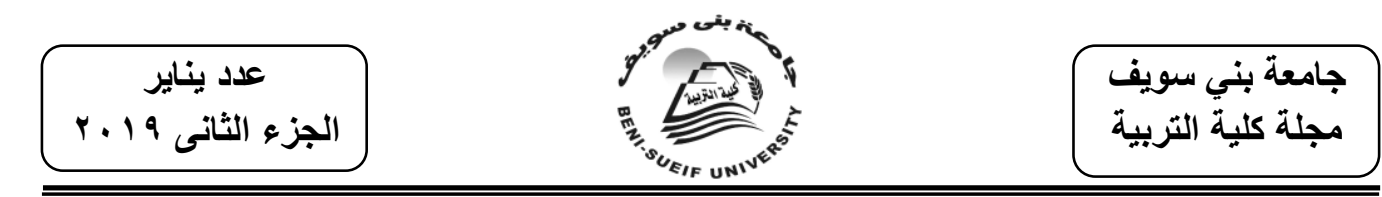

\begin{tabular}{|c|c|c|c|c|c|c|c|}
\hline معامل الارتباط & م & معامل الارتباط & م & معامل الارتباط & r & معامل الارتباط & r \\
\hline **... & or & $* 01 \leq \ldots$ & ب & $* \varepsilon . \varepsilon$. & $r \varepsilon$ & *10.. & 1 . \\
\hline * ... & r & **ๆ人દ.. & rq & $* Y \vee 1 .$. & ro & **⿻上丨.. & 11 \\
\hline$* * \leqslant 07$. & $0 \leqslant$ & $* * 0 \leqslant \wedge$. & $\varepsilon$. & $* * 701$. & ry & **ชา.. & ir \\
\hline$* *, 0 \wedge r$ & 00 & 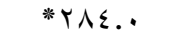 & \&1 & **⿻上丨... & rV & *५९ा.. & r \\
\hline **ฯrV.. & 07 & **⿻rV.. & $\varepsilon Y$ & *广V.. & r人 & ** * TV.. & $1 \varepsilon$ \\
\hline
\end{tabular}

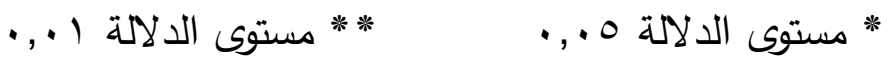

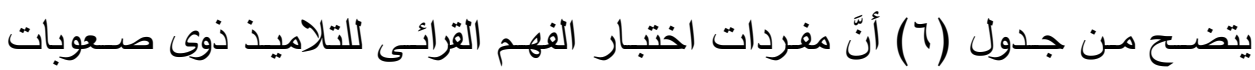

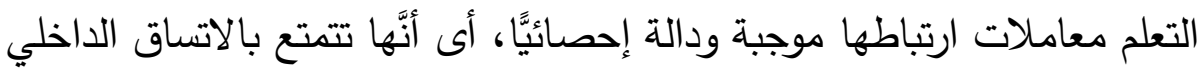

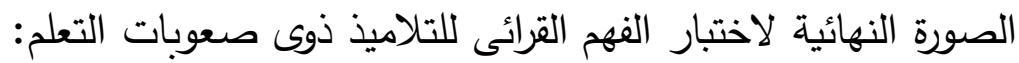

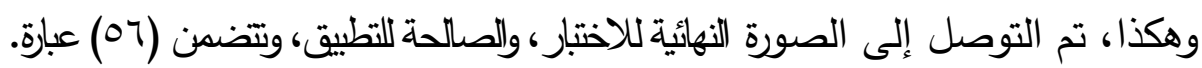
تعليمات الاختبار: ا - يجب عند تطبيق الاختبار خلق جو من الألفة مع التلميذ ذوى صسوبات التعلم، حتى ينعكس ذلك على صدقه فى الإجابة. r- يجب على القائم بتطبيق الاختبار توضيح أنَّه ليس هناك زمن فن محدد للإجابة، كما أنَّ الإجابة ستحاط بسرية تامة. r- يتم التطبيق بطريقة فردية، وذلك للتأكد من عدم العشوائية فى الإجابة.

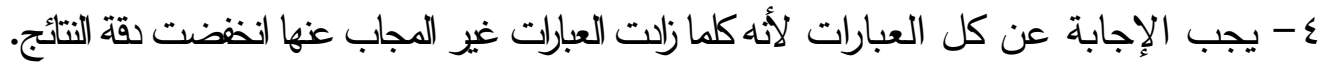
نتائج الدراسة:

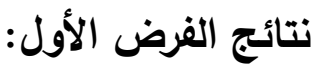
ينص الفرض الأول على أنَّه " توجد علاقة ذات دلالة احصائية بين التعلم النشط والفهم القرائي لدى التلاميذ ذوي صعوبات التعلم".

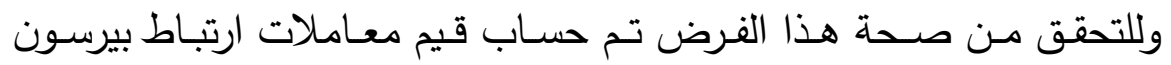
بين التعلم النشط والفهم القرائي، والجدول (Vearson) 
قيم معاملات الارتباط بين درجات أبعاد كل من مقياس التعلم النشط والفهم القرائي لاى الى

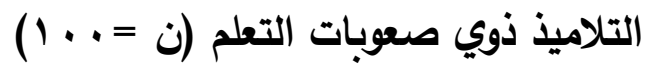

\begin{tabular}{|c|c|c|c|}
\hline الفهر القرائي & ن & عينة الاراسة & \multirow{4}{*}{ التعلم النشط } \\
\hline **,OlV & 0. & الذكور & \\
\hline **, & 0 . & الإناث & \\
\hline$* *, 0 . \wedge$ & 1... & العينة ككل & \\
\hline
\end{tabular}

** دالة عند مستوى دلالة 1 ., ..

يتضـح مـن جدول (V) وجـود علاقـة ارتباطيـة موجبـة ذات دلالــة إحصـائية بـين مقياسي التعلم النشط والفهم القرائي لدى التلاميذ ذوبي صعوبات التعلم عند مستوى دلالتة

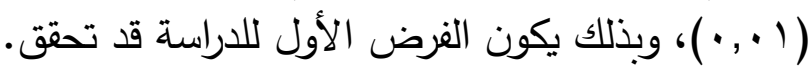

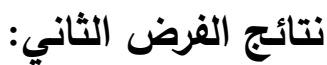
ينص الفرض الثاني على أنَّه " توجد فروق بين متوسطي درجات التعلم النشط لدى

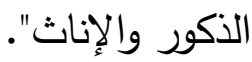
وللتحقق من صـحة هذا الفرض، تـم استخدام اختبار (ت) t-test للمجموعتين، والجدول (^) يوضـح النتيجة.

جدول (^)

المتوسط الحسابي والانحراف المعياري وقيمة ت للتعلم النشط لدى مجموعتى الأكور والإناث

\begin{tabular}{|c|c|c|c|c|c|}
\hline \multirow{2}{*}{ مستوى الدلالة } & \multirow[b]{2}{*}{ قيمة ت } & \multicolumn{2}{|c|}{ الإناث ن = . • } & \multicolumn{2}{|c|}{ الأكور ن = . • } \\
\hline & & الانحراف المعياري & المتوسط الحسابي & المعياري & الحسابي \\
\hline$\cdot,+1$ & $\varepsilon r, r \circ 0$ & $r, Y v$ & $r v, q$. & $1, \leqslant \varepsilon$ & Y1, \&. \\
\hline
\end{tabular}

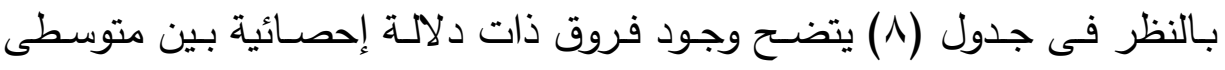

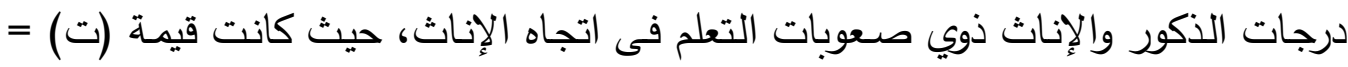

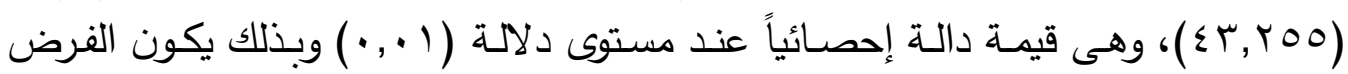
الثاني للدراسة قد تحقق. 
نتائج الفرض الثالث:

ينص الفرض الثالث على أنَّه " توجد فروق بين متوسطي درجات الفهم القرائي

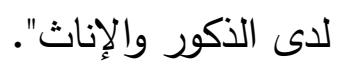

وللتحقق من صـحة هذا الفرض، تم استخدام اختبار (ت) t-test للمجموعتين،

$$
\text { والجدول (9) يوضـح النتيجة. }
$$

جدول (9)

\begin{tabular}{|c|c|c|c|c|c|}
\hline \multirow{2}{*}{ مستوى } & \multirow[b]{2}{*}{ قيمة ت } & \multicolumn{2}{|c|}{ الإناث ن = . • } & \multicolumn{2}{|c|}{ الذكور ن = . • } \\
\hline & & المعياري & الحسابي & الانحراف & الحسابي \\
\hline$\cdot, \cdot 1$ & 11, 1474 & $v, \cdot \Lambda$ & $9 \leqslant, 0$. & 0,00 & V1,1. \\
\hline
\end{tabular}

المتوسط الحسابي والانحراف المعياري وقيمة ت للفهم القرائي للى مجوعتى النكور والإناث

بالنظر فى جدول (9) يتضـح وجود فروق ذات دلالـة إحصـائية بين متوسطى درجات الذكور والإنـاث ذوي صسوبات التعلم فى اتجاه الإنـاث فى الفهم القرائي، حيث

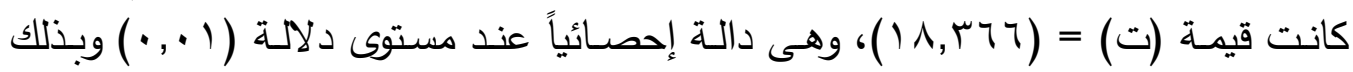
يكون الفرض الثالث للدراسة قد تحقق.

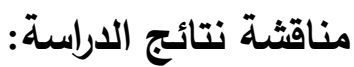
بعد العرض السـابق لنتائج الدراسـة يمكن مناقشتها وتفسيرها في ضـوء الفروض

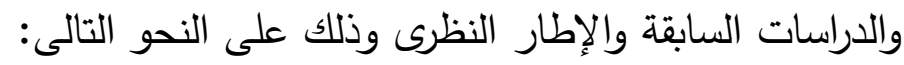

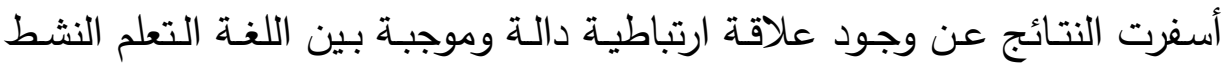

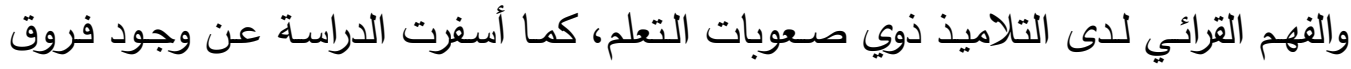

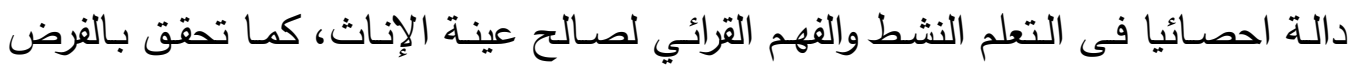
الثاني والثالث.

وهذا ما أشارت إليه كثير من الدراسات والتي منها دراسة \& Filippatou

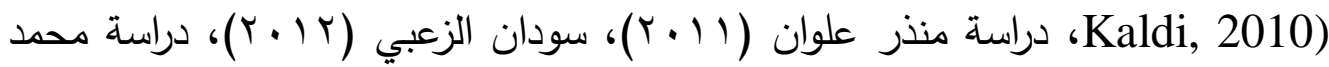

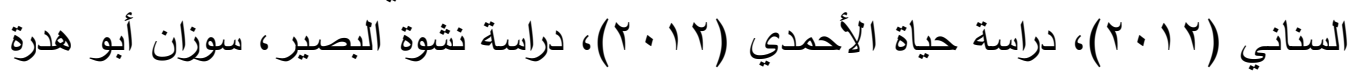

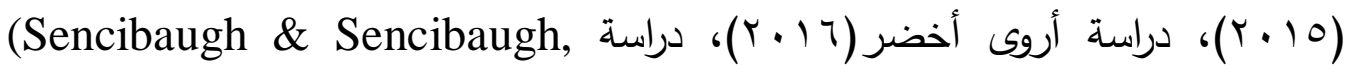
(2016؛ وتتقق أيضا نتائج الدراسة الحالية مع ما توصلت إليه دراسيه دراسات الفهم القرائي 


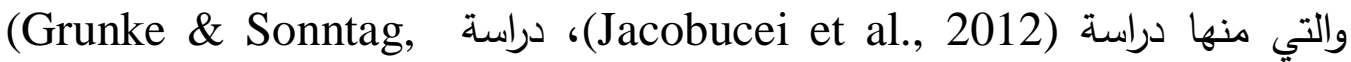

.Georgious \& Das (2016) ،Nevo \& Bar-Kochva (2015) ،2013)

ملخص النتائج: - 2013)

أسفرت نتائج الدراسة عن وجود علاقة ذات دلالة احصائية دالة عند (1 + , •) بين

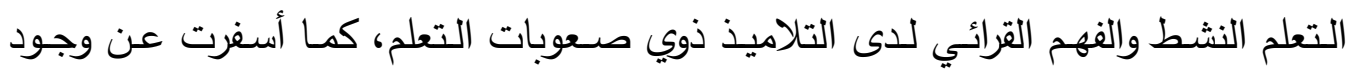
فروق دالة احصـائيا عند (1 (., ·) بين كل من الذكور والإنـاث في التعلم النشط والفهم القرائي لصالح الإناث.

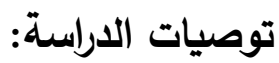

توصى الباحثة استنادًا إلى ما كثفت عنه الدراسة الحالية بما يلى:

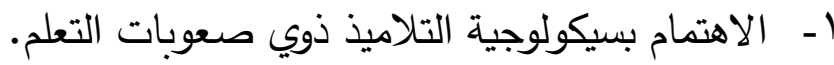

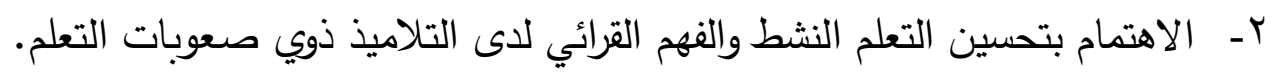

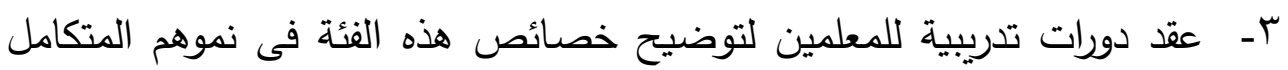
وتحسين سلوكياتهم. دراسات مقترحة:

ماستتادًا إلى الإطار النظرى والدراسات السابقة ونتائج الدراسة الحالية تقترح الباحثة عدد من الموضوعات البحثية التى تحتاج إلى إجراء مزيد من الدراسات للوقوف على نتائجها:

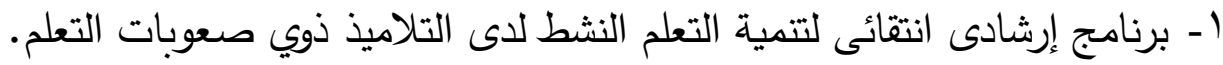
r- برنامج إرشادى لتحسين مستوى الفهم القرائي لدى التلاميذ ذوي صعوبات التهات التعلم. 


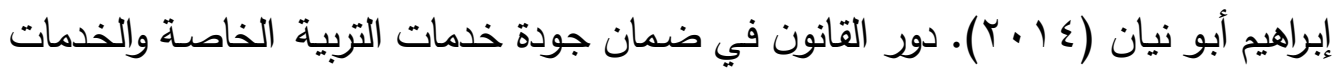

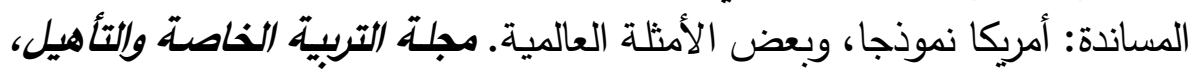

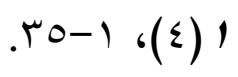

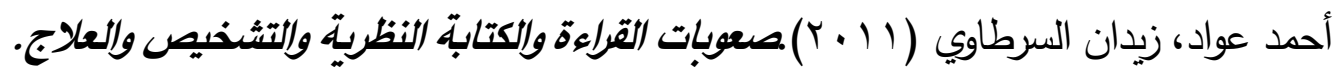

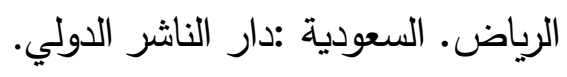

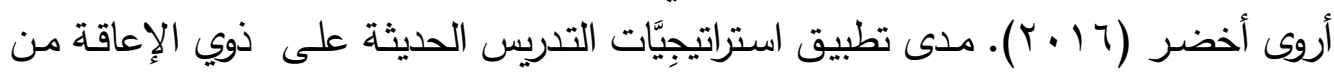

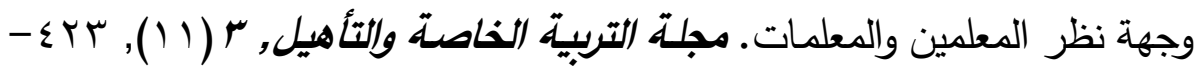

$$
\text { . }
$$

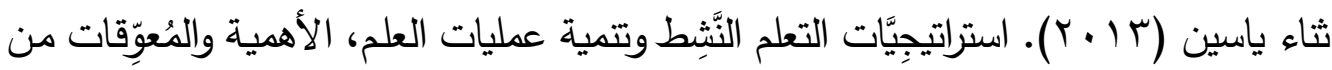

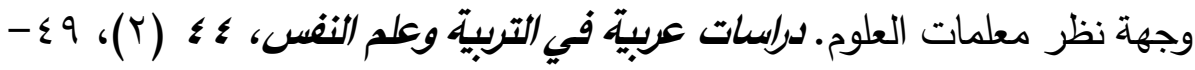

$$
\text { .1.0 }
$$

جمال سليمان عطية (999 (99):فعالية استراتيجية الخريطـة الدلالية فى تتمية مهارات الفهح

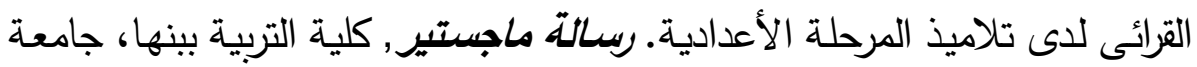

$$
\text { الزقازيق. }
$$

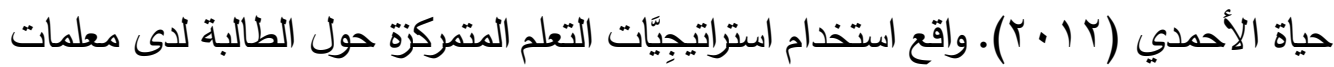

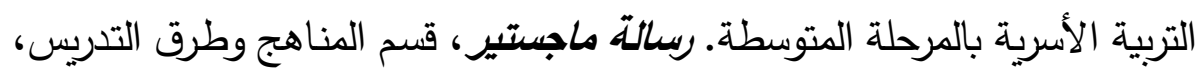

$$
\text { كلية التربية، جامعة طيبة. }
$$

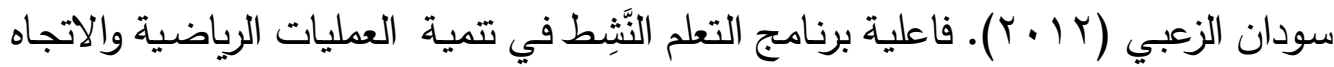

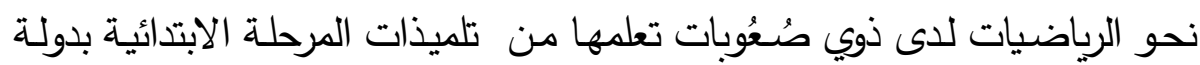

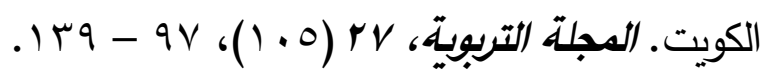

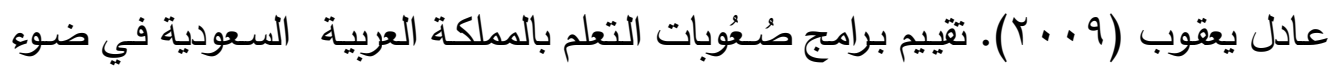

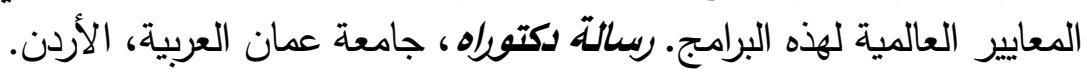

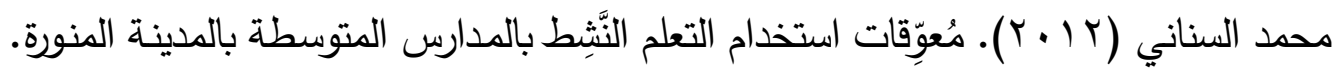

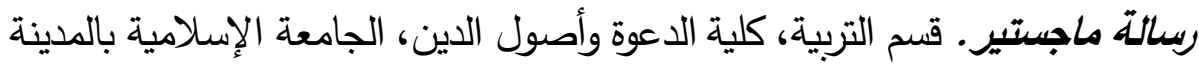


عدد يناير

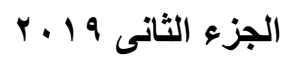

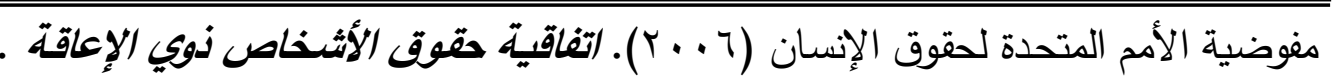

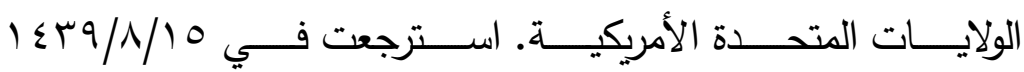
http://www.ohchr.org/AR/HRBodies/CRPD/Pages/ConventionRightsPersonsWit hDisabilities.aspx منذر علوان (11 (ب). فاعلية برنامج تدريبي يستتد إلى التعليم المبرمج في تعليم مهارات

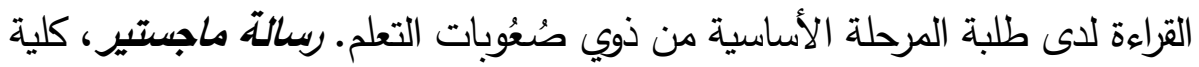
العلوم التربوية والنفسية، جامعة عمان العربية.

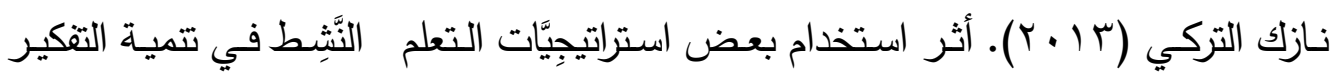

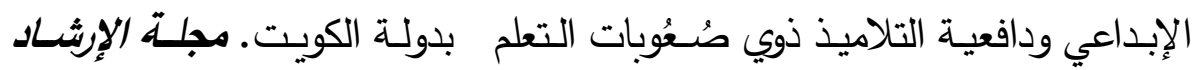

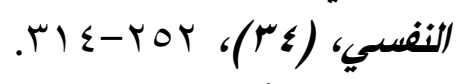

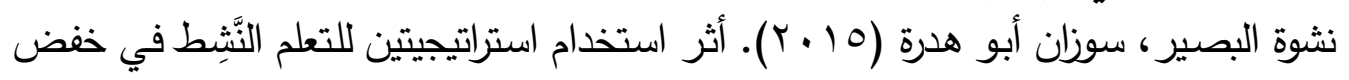

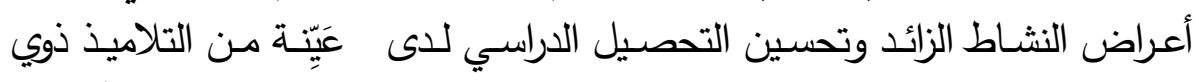

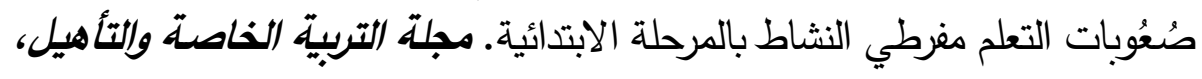

$$
V \leqslant-Y V \text { ، (T) } r
$$

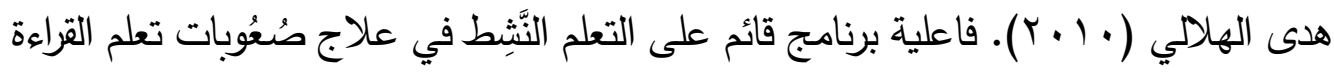

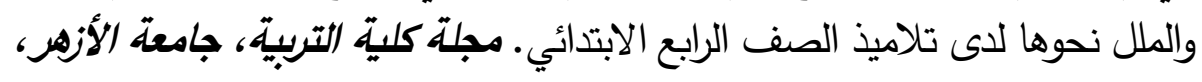

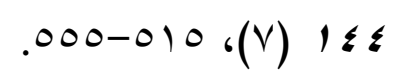

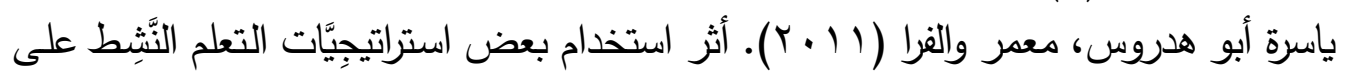

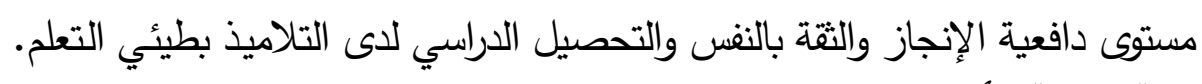

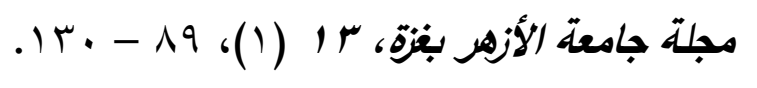


Filippatou, D. Kaldi, S. (2010). The Effectiveness of Project-Based Learning On Pupils with Learning Difficulties Regarding Academic Performance, Grou Work and Motivation, International Journal of Special Education, 25 (1), 41 - 68.

Grunke, M., \& Sonntag .W. (2013). kategoriales lernen und leseverstandnis bei schu lern mit lernbehinderu. ngen / categorical iearning and reading comprehens. ion of pupils with learning disabilities. vierteljahress chrift fyr heilpadagogik und ihre nach bargebiete, 72 (4), 325 - 330.

Karamustafaoglu, O. (2009). Active Learning Strategies in Physics Teaching. Online Submission, 1(1), 27-50.

Nevo, E., \& Bar-Kochva, I. (2015). The Relations Between Early Working Memory Abilities and Later Developing Reading Skills: A Longitudinal Study From Kindergarten to Fifth Grade. International Mind, Brain, and Education Society. 9 (3), $14-24$.

Sencibaugh, J., \& Sencibaugh, A. (2016). An Analysis of Cooperative Learning Approaches for Students with Learning Disabilities. Education, 136 (3), 356-364. 